\title{
Structural Characterization of Cardiolipin by Tandem Quadrupole and Multiple-Stage Quadrupole Ion-Trap Mass Spectrometry with Electrospray Ionization
}

\author{
Fong-Fu Hsu and John Turk \\ Mass Spectrometry Resource, Division of Endocrinology, Diabetes, Metabolism, and Lipid Research, \\ Department of Internal Medicine, Washington University School of Medicine, St. Louis, Missouri, USA
}

Elizabeth R. Rhoades and David G. Russell

Department of Microbiology and Immunology, Cornell University, Ithaca, New York, USA

\author{
Yixin Shi and Eduardo A. Groisman \\ Department of Molecular Microbiology, Washington University School of Medicine, St. Louis, Missouri, USA
}

We report negative-ion electrospray tandem mass spectrometric methods for structural characterization of cardiolipin (CL), a four-acyl-chain phospholipid containing two distinct phosphatidyl moieties, of which structural assignment of the fatty acid residues attached to the glycerol backbones performed by low-energy CAD tandem mass spectrometry has not been previously described. The low-energy $\mathrm{MS}^{2}$-spectra of the $[\mathrm{M}-\mathrm{H}]^{-}$and $[\mathrm{M}-2 \mathrm{H}]^{2-}$ ions obtained with ion-trap or with tandem quadrupole instrument combined with ion-trap $\mathrm{MS}^{3}$-spectra or with source CAD product-ion spectra provide complete structural information for CL characterization. The $\mathrm{MS}^{2}$-spectra of the $[\mathrm{M}-\mathrm{H}]^{-}$ions contain two sets of prominent fragment ions that comprise a phosphatidic acid, a dehydrated phosphatidylglycerol, and a (phosphatidic acid +136 ) anion. The substantial differences in the abundances of the two distinct phosphatidic anions observed in the $\mathrm{MS}^{2}$-spectra of the $[\mathrm{M}-\mathrm{H}]^{-}$ions lead to the assignment of the phosphatidyl moieties attached to the $1^{\prime}$ or $3^{\prime}$ position of central glycerol. Upon further collisional dissociation, the $\mathrm{MS}^{3}$-spectra of the phosphatidic anions provide information to identify the fatty acyl substituents and their position in the glycerol backbone. The $\mathrm{MS}^{2}$-spectra of the $[\mathrm{M}-2 \mathrm{H}]^{2-}$ ions obtained with TSQ or ITMS contain complementary information to confirm structural assignment. The applications of the above methods in the differentiation of cardiolipin isomers and in the identification of complex cardiolipin species consisting of multiple molecular structures are also demonstrated. (J Am Soc Mass Spectrom 2004, 16, 491-504) (C 2004 American Society for Mass Spectrometry

C ardiolipin (CL) (I) contains a phosphatidylglycerol that is linked to the phosphoglyceride skeleton to make it a 1,3-bisphosphatidyl-sn-glycerol $[1,2]$. The compound was first isolated by Pangborn [3]. The trivial name "cardiolipin" is derived from the fact that it was first found in animal hearts, where it is especially abundant and mostly confined to the mitochondria, comprising more than $10 \%$ of the total phospholipids of that organ. It can also be found in mitochondria of all animal tissues and of the eukaryotic kingdom [4].

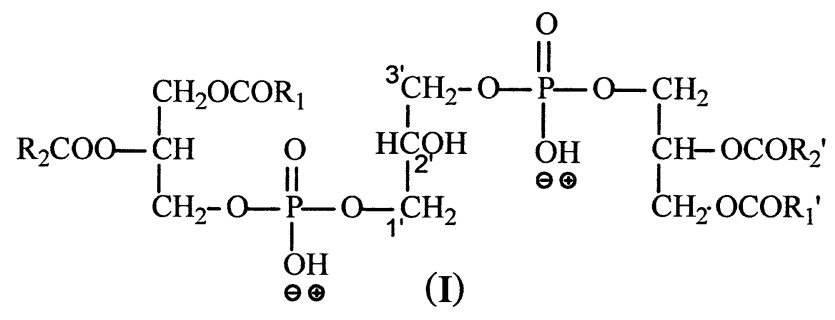

Cardiolipin is essential for the function of several enzymes of oxidative phosphorylation, and thus, for production of energy for the heart to beat $[5,6]$. A direct relationship between CL loss and cytochrome $c$ release from the mitochondria has been identified as an initial step in the pathway to apoptosis [7, 8]. An absolute requirement for $\mathrm{CL}$ in the function of crucial mitochon- 
drial proteins, e.g., cytochrome oxidase and the adenine nucleotide translocase, are likely additional factors impacting apoptosis and cellular energy homeostasis [5-9]. Other potential clinical manifestations of perturbations of CL synthesis are associated with, for instance, Barth Syndrome, where a primary defect can be attributed to CL metabolism and is associated with dilated cardiomyopathy $[10,11]$. The regulatory properties that govern CL biosynthesis, its remodeling, and trafficking are beginning to emerge [5-9, 12].

Two pathways are involved in the synthesis of cardiolipin. In the prokaryotic biosynthesis pathway, two molecules of phosphatidylglycerol were involved. In contrast, cardiolipin was synthesized from CDPdiacylglycerol and phosphatidylglycerol in the common eukaryotic mechanism [12-14]. The gross structures of the major cardiolipin species from different sources are very similar. For example, the molecular species of cardiolipin from rat liver, bovine heart, $S$. cerevisiae and $N$. crassa contained mainly $16: 0$ or $18: 2$ fatty acid, resulting in a relatively homogeneous distribution of double bonds and carbon numbers among the four acyl positions [14, 15].

The complexities of the molecular species of cardiolipin stem not only from the diversity of different chain lengths for fatty acids and the fatty acids with varying degrees of unsaturation, but also from permutations of the four fatty acyl chains that result in a large number of potential combinations. Thus, unraveling the structure of cardiolipin has been a very difficult task and has been previously approached by a rather complicated method that requires analysis of the total fatty acyl patterns and the positional distribution of acyl chains between $s n-1$ and sn-2 positions, analysis of diacyl species of the 1 '-phosphatidyl and 3'-phosphatidyl moieties and the resolution of tetraacyl species of derivatized cardiolipin. This approach in the analysis of CL has been mainly conducted by high-performance liquid chromatographic separation of its 1,3-bisphosphatidyl-2benzoyl-sn-glycerol dimethyl ester derivative, followed by characterization of the derivatives involving ${ }^{1} \mathrm{H}$ nuclear magnetic resonance spectroscopy, ultraviolet (uv) spectroscopy, thin-layer chromatography, and fatty acid analysis [15, 16].

ESI with tandem mass spectrometric methods including tandem quadrupole [10], quadrupole-time of flight (Q-TOF) [17], and ion-trap [18] instruments have been attempted for characterization of cardiolipin and glucosylcardiolipin, and result in identifying but not locating the fatty acyl substituents on the glycerol backbone. The subclasses of cardiolipin of glucosyl-, alanyl-, and lysocardiolipins also have been previously characterized by FAB-sector mass spectrometric method, but the structural detail including position of the fatty acyl substituents on the glycerol backbone cannot be determined [19]. Herein, we present tandem mass spectrometric methods using both a triple quadrupole and a quadrupole ion-trap mass spectrometer to characterize cardiolipins isolated from various biologi- cal sources. Structures of regio- and configuration isomers of cardiolipin molecules are revealed in details.

\section{Materials and Methods}

\section{Isolation of Cardiolipins}

Cardiolipin from bovine heart and bis-(1,2-dimyristorysn-glycero-3-phosphoryl)-1', 3'-sn-glycerol [(14:0/14:0) (14:0/14:0)-CL] standard were purchased from Avanti Polar Lipid (Alabaster, AL). Cardiolipins from bacterium Salmonella typhimurium and from Mycobacterium bovis BCG were isolated using the procedures as previously described [20, 21].

\section{Mass Spectrometry}

Low-energy CAD tandem mass spectrometry experiments were conducted on a Finnigan (San Jose, CA) TSQ 7000 mass spectrometer equipped with ICIS data system or on a LCQ DECA ion-trap mass spectrometer (ITMS) with X-calibur operation system. Extracts containing cardiolipin (10 to $50 \mathrm{pmol} / \mu \mathrm{L}$ ) in methanol/ chloroform solution (vol/vol, 1/1) were continuously infused ( $1 u \mathrm{~L} / \mathrm{min}$ ) to the ESI source, where the skimmer was set at ground potential, the electrospray needle was at $4.5 \mathrm{kV}$, and temperature of the heated capillary was at $260{ }^{\circ} \mathrm{C}$. This gives both $[\mathrm{M}-\mathrm{H}]^{-}$and $[\mathrm{M}-$ $2 \mathrm{H}]^{2-}$ ions in the negative-ion mode. For product-ion spectra obtained with a triple stage quadrupole (TSQ) instrument, the precursor ions were selected in the first quadrupole (Q1), collided with Ar (2.3 mTorr) in the rf-only second quadrupole (Q2), and analyzed in the third quadrupole (Q3). The collision energies were set at 22 to $24 \mathrm{eV}$ for the $[\mathrm{M}-2 \mathrm{H}]^{2-}$ ions and at 46 to $50 \mathrm{eV}$ for the $[\mathrm{M}-\mathrm{H}]^{-}$ions. Both $\mathrm{Q} 1$ and Q3 were tuned to unit mass resolution and scanned at a rate of $3 \mathrm{sec} / \mathrm{scan}$. The mass spectra were accumulated in the profile mode, typically for 5 to $10 \mathrm{~min}$ for a tandem mass spectrum. For CAD tandem mass spectra obtained with a quadrupole ion-trap instrument, the automatic gain control of the ion trap was set to $5 \times 10^{7}$, with a maximum injection time of $400 \mathrm{~ms}$. Helium was used as the buffer and collision gas at a pressure of $1 \times 10^{-3}$ mbar. $\mathrm{MS}^{\mathrm{n}}$ experiments were carried out with a relative collision energy ranged from 30 to $35 \%$ and with an activation $q$ value, with which the desired mass range for the product-ion scan can be set. The activation time was set at $100 \mathrm{~ms}$. The mass resolution was $0.6 \mathrm{Da}$ at half peak height throughout the acquired mass range.

\section{Results and Discussion}

Cardiolipin possesses two phosphate charge sites, and forms both $[\mathrm{M}-\mathrm{H}]^{-}$and $[\mathrm{M}-2 \mathrm{H}]^{2-}$ ions when being subjected to ESI in the negative-ion mode. Beckedorf et al. ${ }^{\circ}[17]^{\circ}$ reported ${ }^{\circ}$ that ${ }^{\circ}\left[\mathrm{M}^{\circ}-{ }^{\circ} 2 \mathrm{H}^{\circ}+{ }^{\circ} \mathrm{Na}\right]^{-{ }^{\circ}}$ and ${ }^{\circ}\left[\mathrm{M}^{\circ}-{ }^{\circ} 3 \mathrm{H}^{\circ}+\right.$ $\mathrm{Na}]^{2-}$ ions are the major ions observed for D-glucopyranosylcardiolipin using Q-TOF instrument equipped 

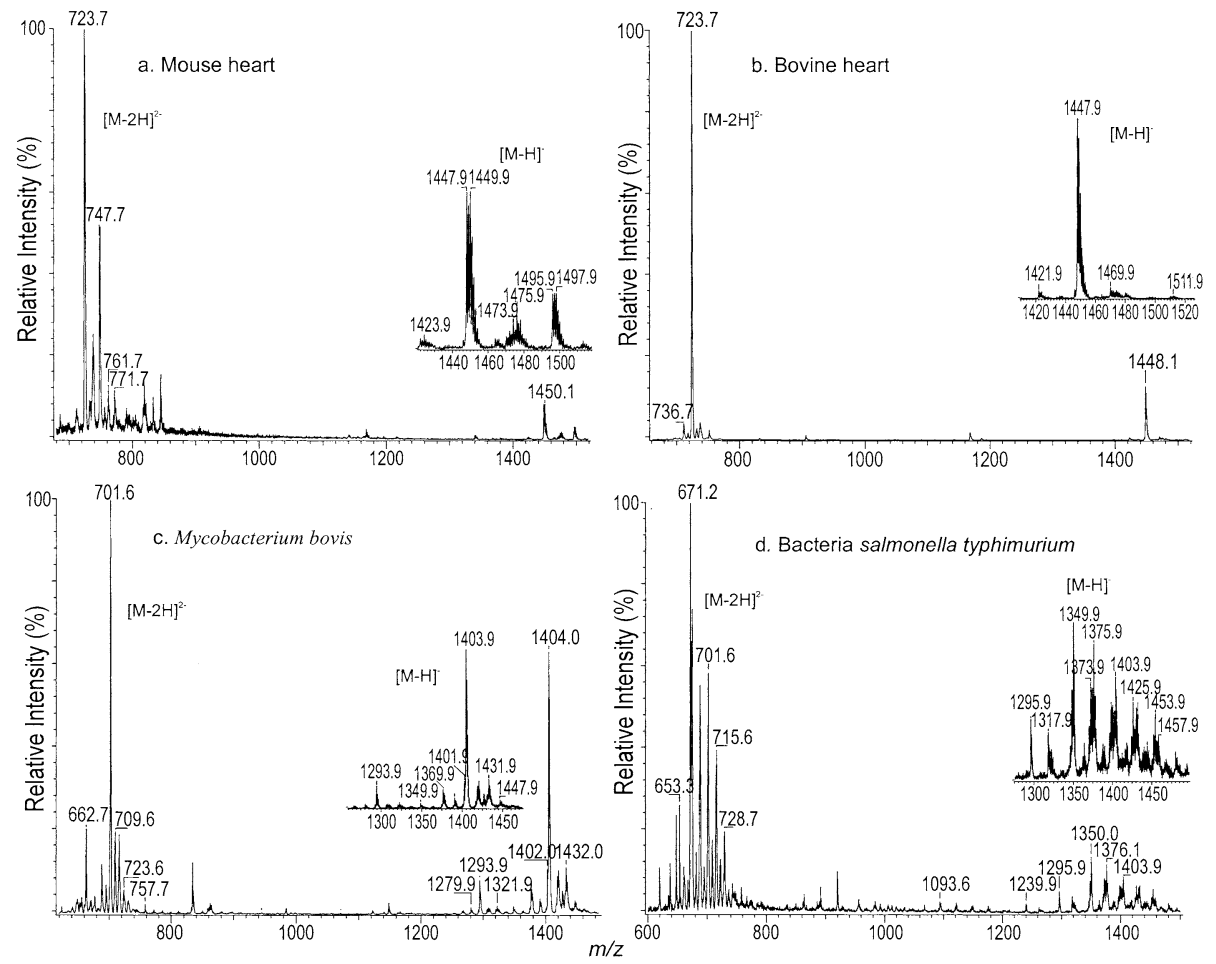

Figure 1. The ESI/MS spectra of cardiolipin mixture isolated from mouse heart (a), bovine heart (b), Mycobacterium bovis (c), and bacterium Salmonella typhimurium (d) obtained with a TSQ instrument.

with a nanospray source, and the $[\mathrm{M}-2 \mathrm{H}+3 \mathrm{Na}]^{+}$ ions with lesser sensitivity were also observed in the positive-ion mode. However, these ions were not observed in our study, probably attributable to the fact that our CL extracts contained less $\mathrm{Na}^{+}$. This was achieved by dissolving the sample in $50 \%$ methanol (with $0.01 \% \mathrm{NH}_{4} \mathrm{OH}$ ), followed by extraction with chloroform. This clean-up step also resulted in two to three time increases in the detection of $[\mathrm{M}-\mathrm{H}]^{-}$and $[\mathrm{M}-2 \mathrm{H}]^{2-}$ ions, with the latter ion is three times more abundant $^{\circ}$ than $^{\circ}$ the ${ }^{\circ}$ former. ${ }^{\circ}$ Figure $^{\circ} 1^{\circ}$ illustrates $^{\circ}$ the ESI/MS profiles of the cardiolipins isolated from mouse heart (Panel a), bovine heart (Panel b), Mycobacterium bovis BCG (Panel c), and bacterium Salmonella typhimurium (Panel d) obtained with a TSQ instrument. The spectra demonstrate the diversities of cardiolipin of biological origins, and are similar to those obtained with an ITMS instrument (data not shown). The spectra contain homologous $[\mathrm{M}-\mathrm{H}]^{-}$ions and the $[\mathrm{M}-2 \mathrm{H}]^{2-}$ species. Structural characterizations of the individual molecular species are described below.

\section{The Fragmentation Processes Revealed by Tandem Quadrupole and Ion-Trap Mass Spectrometry of Cardiolipin Standard and Its Deuterium Analog}

To simplify data interpretation, we adopt the rules recommended by IUPAC with modification for designation of CL. Briefly, the three glycerol moieties are

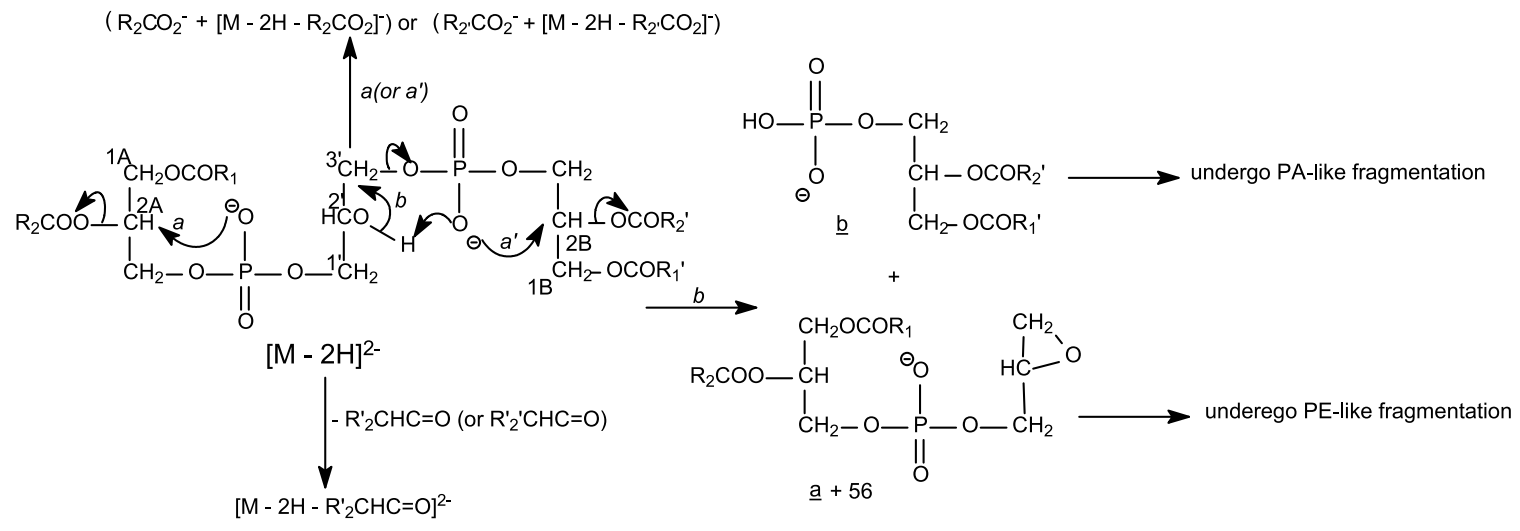

Scheme 1. The major fragmentation pathways proposed for the $[\mathrm{M}-2 \mathrm{H}]^{2-}$ ions of CL. 

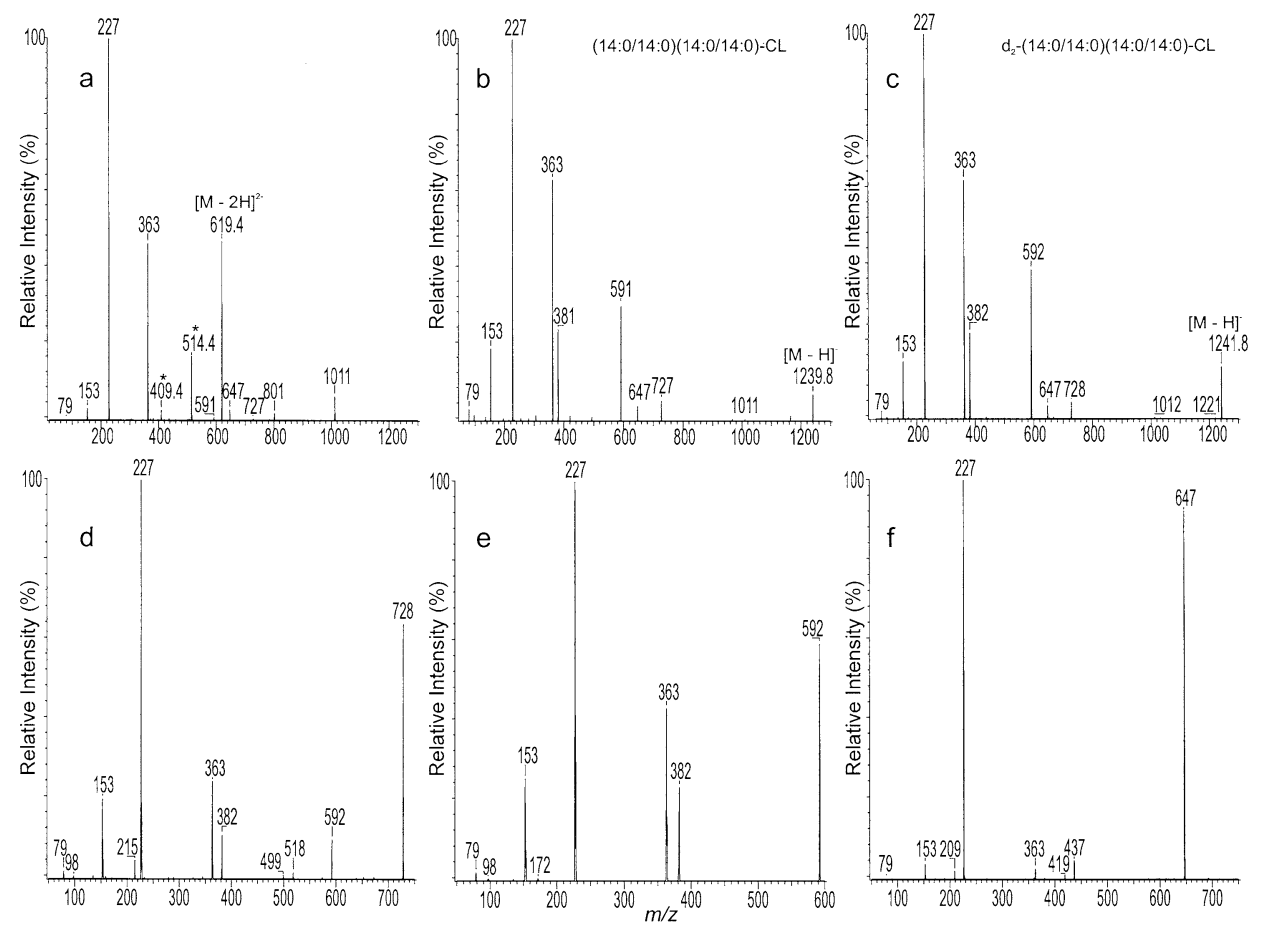

Figure 2. The tandem quadrupole product-ion spectra of (a) the $[\mathrm{M}-2 \mathrm{H}]^{2-}$ ion at $\mathrm{m} / \mathrm{z} 619.6$, (b) the $[\mathrm{M}-\mathrm{H}]^{-}$ion at $m / z 1239$ of the (14:0/14:0)(14:0/14:0)-CL standard; (c) is the product-ion spectrum of the $[\mathrm{M}-\mathrm{H}]^{-}$ion of $\mathrm{d}_{2}-(14: 0 / 14: 0)(14: 0 / 14: 0)-C L$ standard at $\mathrm{m} / z$ 1241, of which the exchangeable hydrogens have been substituted by deuterium atoms via $\mathrm{H}-\mathrm{D}$ exchange. The mass shift(s) to $\mathrm{m} / \mathrm{z} 1012$ $\left(\right.$ from $\left.^{\circ} 1011\right),{ }^{\circ} 728^{\circ}\left(\right.$ from $\left.^{\circ} 727\right),{ }^{\circ}$ and $^{\circ} 592^{\circ}\left(\text { from }^{\circ} 591\right)^{\circ}$ observed $^{\circ}$ in $^{\circ}$ Figure $^{\circ} 2 \mathrm{c}^{\circ},{ }^{\circ}$ along $^{\circ}$ with $^{\circ}$ the ${ }^{\circ}$ product-ion spectra of the $m / z 728(\mathbf{d}), m / z 592(\mathbf{e})$, and $m / z 647(\mathbf{f})$ ions generated by source CAD of the $[\mathrm{M}-\mathrm{H}]^{-}$ ion of $d_{2}-(14: 0 / 14: 0)(14: 0 / 14: 0)-C L$ suggest the fragmentation pathways as proposed in Scheme 2 . The peaks labeled with a star symbol in all the figures denote doubly-charged fragment ions.

designated as A, B, and central glycerol (Scheme 1). The stereospecific numberings ( $s n$ ) of the $\mathrm{C} 1 \mathrm{~A}$ and $\mathrm{C} 2 \mathrm{~A}$ carbons (Glycerol A) are designated as $s n-1$ and $s n-2$, respectively. The $\mathrm{C} 1 \mathrm{~B}$ and $\mathrm{C} 2 \mathrm{~B}$ carbons (Glycerol B) are designated as $s n-1^{\prime}$ and $s n-2^{\prime}$, respectively. The carbon number of the central glycerol is designated as $\mathrm{C}-1^{\prime}$, C-2' and C-3' with the C-1' attached to the phosphatidic moiety with Glycerol A. Abbreviation of cardiolipin, such as (16:0/16:1)(18:0/18:1)-CL signifies that the 16:0-, 16:1-, 18:0-, and 18:1-fatty acyl substituents attach to C1A, C2A, C1B, and C2B, respectively.

The synthetic (14:0/14:0)(14:0/14:0)-CL standard contains four identical 14:0-acyl substituents residing at $s n-1, s n-2$ (Glycerol A), sn-1' and at sn-2' (Glycerol B). The compound gives an $[\mathrm{M}-\mathrm{H}]^{-}$ion at $m / z 1239$ and an $[\mathrm{M}-2 \mathrm{H}]^{2-}$ ion at $m / z 619.4$. Selection and CAD of

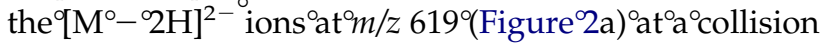
energy of $22 \mathrm{eV}$ yield the 14:0-carboxylate anion at $\mathrm{m} / \mathrm{z}$ 227 , reflecting the uniform fatty acyl moiety of the molecule. The product-ion spectrum also contains the $\mathrm{m} / \mathrm{z} 514.4$ ion, a doubly-charged fragment ion arising from loss of the 14:0-fatty acyl substituent as a ketene $(619.4 \times 2-210) / 2$. However, ions corresponding to loss of the fatty acyl substituents as acids were not observed, consistent with the hypothesis that the [M $2 \mathrm{H}]^{2-}$ ion, which contains one less proton than does the $[\mathrm{M}-\mathrm{H}]^{-}$ion, is a basic precursor ion and undergoes more facilequetenethan acid loss 922$].$ The $\mathrm{R}_{\mathrm{x}} \mathrm{CO}_{2}{ }^{-}$ion at $\mathrm{m} / \mathrm{z} 227$ mainly arises from nucleophilic attack of the anionic phosphate charge site onto $\mathrm{C}(2 \mathrm{~A})$ or $\mathrm{C}(2 \mathrm{~B})$ of the glycerol (Scheme 1). This fragmentation process also gives rise to $m / z 1011(619 \times 2-227)$.

In contrast, the $[\mathrm{M}-\mathrm{H}]^{-}$ion at $\mathrm{m} / \mathrm{z} 1239$ yields the $m / z 1011(1239-228)$ ion by elimination of a tetradecanoic $^{\circ}$ acid $^{\circ}$ (Figure $\left.^{\circ} 2 \mathrm{~b}\right)^{\circ}\left(\right.$ in $^{\circ}$ the $^{\circ} \mathrm{IT}^{\circ} \mathrm{MS}^{2}$-spectrum ${ }^{\circ}$ as shown ${ }^{\circ}$ in $^{\circ}{ }^{\circ}$ igure ${ }^{\circ} 3 b,{ }^{\circ}$ this ${ }^{\circ}{ }^{\circ}{ }^{\circ}{ }^{\circ}$ is $^{\circ}$ more ${ }^{\circ}$ prominent). ${ }^{\circ}$ The spectrum also contains ions at $m / z$ 591 ( $a$ and $b$ ion), $m / z$ $647[(b+56)$ and $(a+56)]$, and $m / z 727[(a+136)$ and $(b+136)]$ (Scheme 2). The formation of these ions involves the participation of the exchangeable hydrogens. This is supported by the product-ion spectrum of $\mathrm{d}_{2}-(14: 0 / 14: 0)(14: 0 / 14: 0)-\mathrm{CL}^{\circ}{ }^{\circ} \mathrm{t}^{\circ} \mathrm{m} / \mathrm{z}$ 1241(Figure $\left.{ }^{\circ} 2 \mathrm{c}\right)$, ${ }^{\circ}$ of which the exchangeable hydrogens at the central glycerol and at phosphate have been substituted by deuterium atoms via $\mathrm{H}-\mathrm{D}$ exchange. The spectrum contains the analogous ions at $m / z 592$ and 728 with a mass shift of $1 \mathrm{Da}$, and at $\mathrm{m} / \mathrm{z} 647$ with no mass shift. This is consistent with the proposed mechanism as shown in Scheme 2 [the hydrogen atoms that were exchanged by deuterium atoms are denoted as "(D)"]. The $m / z 591$ is structurally equivalent to a deprotonated dimyristoryl phosphatidic (14:0/14:0-PA) anion, which arises from $\mathrm{m} / \mathrm{z} 727$ by neutral loss a tricylic glycerophosphate ester moiety ${ }^{\circ}$ of $^{\circ} 136^{\circ}\left(\text { Scheme }^{\circ} 2 \mathbf{2 a}\right)^{\circ}[23-25]^{\circ} .^{\circ}$ This ${ }^{\circ}$ fragmentation 

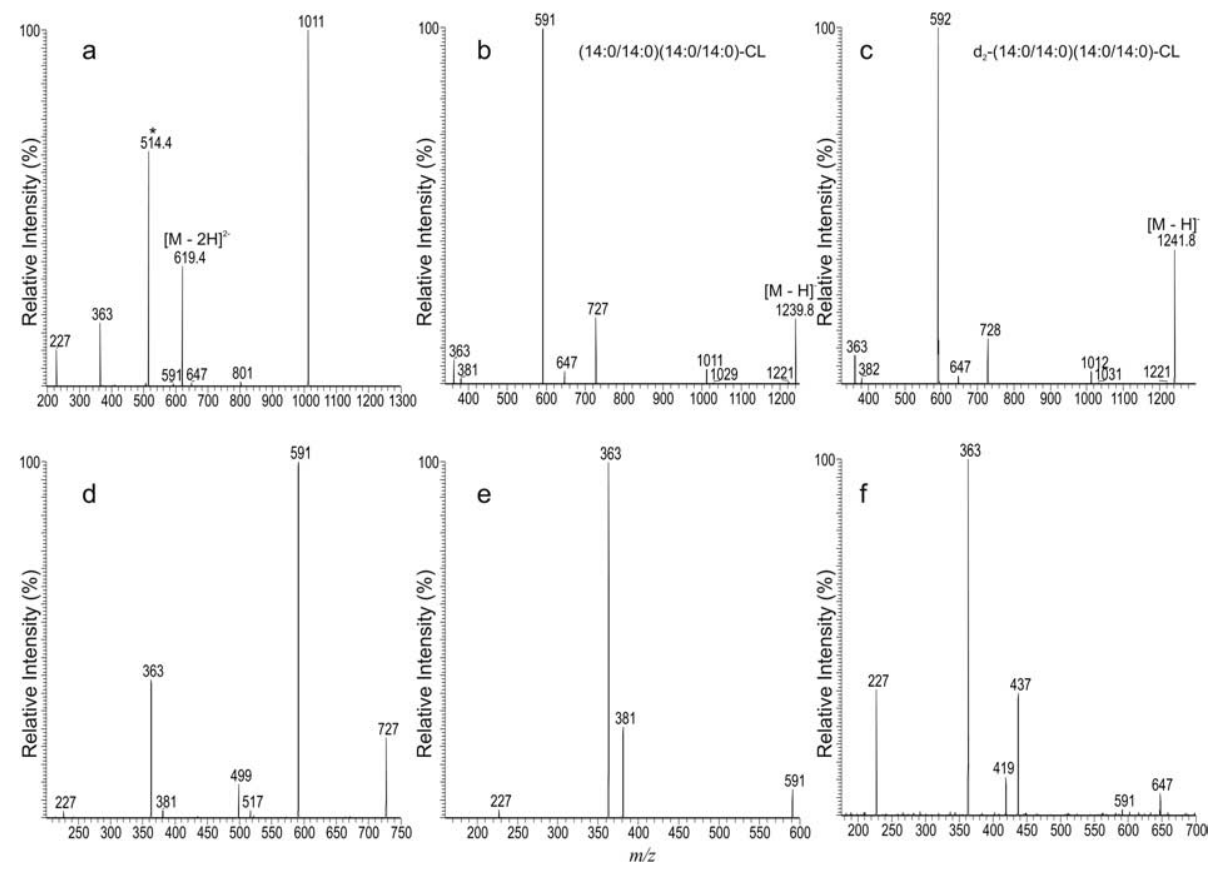

Figure 3. The ion-trap $\mathrm{MS}^{2}$-spectra of (a) the $[\mathrm{M}-2 \mathrm{H}]^{2-}$ ion at $m / z 619.4,(\mathbf{b})$ the $[\mathrm{M}-\mathrm{H}]^{-}$ion at $m / z$ 1239 of the (14:0/14:0)(14:0/14:0)-CL standard; (c) is the $\mathrm{MS}^{2}$-spectrum of the $[\mathrm{M}-\mathrm{H}]^{-}$ion of $\mathrm{d}_{2}-(14: 0 / 14: 0)(14: 0 / 14: 0)-C L\left(\mathrm{~m} / \mathrm{z}\right.$ 1241)prepared by H-D exchange. The MS ${ }^{3}$-spectra of $\mathrm{m} / \mathrm{z} 727(1239$ $\rightarrow 727)(\mathbf{d}), m / z 591(1239 \rightarrow 591)$ e), and $m / z 647(1239 \rightarrow 647)(\mathbf{f})$ support the mechanisms depicted in Scheme 2 .

pathway is supported by the source-CAD product-ion spectrum of $\mathrm{m} / \mathrm{z} 727$ (not shown) arising from the [M $\mathrm{H}]^{-}$ion of (14:0/14:0)(14:0/14:0)-CL at $\mathrm{m} / \mathrm{z} 1239$, and of the ${ }^{\circ} \mathrm{m} / z 7^{2} 8^{\circ}$ ion $^{\circ}$ (Figure $\left.{ }^{\circ} 2 \mathrm{~d}\right)^{\circ}$ arising $^{\circ}$ from ${ }^{\circ}$ the ${ }^{\circ}\left[\mathrm{M}^{\circ}-{ }^{\circ} \mathrm{H}\right]^{-}$ ion of $\mathrm{d}_{2}-(14: 0 / 14: 0)(14: 0 / 14: 0)-\mathrm{CL}$ at $\mathrm{m} / \mathrm{z}$ 1241. The spectrum is similar to the source-CAD product-ion spectrum $^{\circ}$ of $^{\circ} \mathrm{m} / \mathrm{z} 55^{\circ} 2^{\circ}$ (Figure $\left.{ }^{\circ} 2 \mathrm{e}\right)^{\circ}$ arising $^{\circ}$ from ${ }^{\circ} \mathrm{m} / \mathrm{z}$ 1241, confirming the fragmentation process. The proposed structure of the $m / z 647$ ion $[(b+56)$ ion] resulting from the fragmentation process (Scheme $\mathbf{2 b}$ ) is also consistent with the hypothesis that the $\mathrm{m} / \mathrm{z} 647$ is a basic ion, which undergoes fragmentation processes similar to those observed for phosphatidylethanolamine (PE) and gives rise to a higher abundance of the $\mathrm{m} / \mathrm{z} 437$ ion $(647-210)$ than ${ }^{\circ}$ of ${ }^{\circ}$ the $\mathrm{m} / \mathrm{z} 419^{\circ}$ ion $^{\circ}\left(647^{\circ}-{ }^{\circ} 228\right)^{\circ}$ upon $^{\circ} \mathrm{CAD}^{\circ}$ (Figure 2f), due to the ${ }^{\circ}$ preferential $\%^{\circ}$ oss $^{\circ}$ of the $14: 0^{\circ}$ fatty ${ }^{\circ}$ acyl ${ }^{\circ}$ as ${ }^{\circ}$ a ketene ${ }^{\circ} \operatorname{than}^{\circ} \operatorname{as}^{\circ} \operatorname{an}^{\circ}$ acid $^{\circ}[26]$.

The ion-trap $\mathrm{MS}^{2}$-spectra of the $[\mathrm{M}-2 \mathrm{H}]^{2-}$ ion (Figure $\left.{ }^{\circ} 3 \mathrm{a}\right)^{\circ}$ and ${ }^{\circ}$ of $^{\circ}$ the ${ }^{\circ}\left[\mathrm{M}^{\circ}-{ }^{\circ} \mathrm{H}\right]^{-}{ }^{\circ}$ ion $^{\circ}$ (Figure $3 b$ ) ${ }^{\circ}$ arising from (14:0/14:0)(14:0/14:0)-CL, and of the $[\mathrm{M}-\mathrm{H}]^{-}$ion arising from $\mathrm{d}_{2}-(14: 0 / 14: 0)(14: 0 / 14: 0)-\mathrm{CL}^{\circ}$ (Figure $\left.{ }^{\circ} 3 \mathrm{c}\right)$ contain ions similar to those obtained with TSQ instrument. The IT MS $^{3}$-spectra of $\mathrm{m} / \mathrm{z} 727(1239 \rightarrow 727)$ (Figure $\left.{ }^{\circ} 3 \mathrm{~d}\right),{ }^{\circ} \mathrm{m} / \mathrm{z} 591^{\circ}\left(1239^{\circ} \rightarrow 591\right)^{\circ}\left(\right.$ Figure $\left.^{\circ} 3 \mathrm{e}\right),{ }^{\circ}$ and $^{\circ} \mathrm{m} / \mathrm{z}$ $647^{\circ}\left(1239^{\circ} \rightarrow 647\right)^{\circ}\left(\text { Figure }^{\circ} \mathrm{f}\right)^{\circ}$ also ${ }^{\circ}$ Contain $^{\circ}$ ions ${ }^{\circ}$ similar ${ }^{\circ}$ to those acquired by TSQ and further support the proposed mechanism. However, carboxylate anions at $\mathrm{m} / \mathrm{z}$ $227^{\circ}$ are $^{\circ}$ not $^{\circ}$ observed $^{\circ}$ in $^{\circ}$ Figures $^{\circ} 3 \mathrm{~b}^{\circ}$ and ${ }^{\circ} \mathrm{c}^{\circ}$ because $^{\circ}$ of low-mass cut-off nature of ITMS. The $\mathrm{m} / \mathrm{z} 227$ ion is of

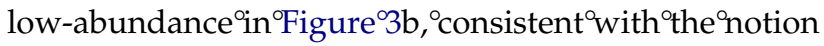
that the carboxylate anions observed in the product-ion spectra obtained by TSQ arise mainly from consecutive fragmentation ${ }^{\circ}$ processes $^{\circ}[22,23,26]$.

\section{Structural Characterization of Cardiolipins with} Symmetric Acyl Moieties by CAD Product-Ion Spectra of the $[\mathrm{M}-\mathrm{H}]^{-}$and $[\mathrm{M}-2 \mathrm{H}]^{2-}$ Ions

The carboxylate anion reflecting the fatty acyl substituent at $s n-1$ (or $\left.s n-1^{\prime}\right)$ is more abundant than the corresponding ion reflecting that at $s n-2$ (or $s n-2^{\prime}$ ) in the product-ion spectra of the $[\mathrm{M}-\mathrm{H}]^{-}$ions, while the abundances of these two carboxylate ions are reversed in the product-ion spectra of the $[\mathrm{M}-2 \mathrm{H}]^{2-}$ ions. As shown in ${ }^{\circ}$ Figure ${ }^{\circ}$, the ${ }^{\circ} \mathrm{R}_{2} \mathrm{CO}_{2}{ }^{-}$(or $\mathrm{R}_{2}, \mathrm{CO}_{2}{ }^{-}$) ion at $\mathrm{m} / \mathrm{z}$ 253 is more abundant than the $\mathrm{R}_{1} \mathrm{CO}_{2}{ }^{-}$(or $\mathrm{R}_{1}, \mathrm{CO}_{2}{ }^{-}$) ion at $\mathrm{m} / \mathrm{z} 255$ in the product-ion spectrum of the [M $2 \mathrm{H}]^{2-}$ ion of $(16: 0 / 16: 1)(16: 0 / 16: 1)-C L$ at $\mathrm{m} / z 673.6$ (Panel a) but the $m / z 255$ ion is more abundant than the $\mathrm{m} / \mathrm{z} 253$ ion in the product-ion spectrum of the [M $\mathrm{H}]^{-}$ion at $\mathrm{m} / \mathrm{z} 1347$ (Panel b), obtained with a TSQ instrument. This reversal in the abundances of the carboxylate anions observed for precursors of cardiolipin with different charge states is similar to that reported $^{\circ}$ for $^{\circ}$ phosphatidylinositol $^{\circ}$ bisphosphate ${ }^{\circ}$ [22] and provides complementary information to confirm the position of fatty acyl substituents on the glycerol backbone.

Both the 1'- and 3 '-phosphate anionic sites of the [M $-2 \mathrm{H}]^{2-}$ precursors render nucleophilic attack on the carbons of the glycerol backbone to which the fatty acyl 

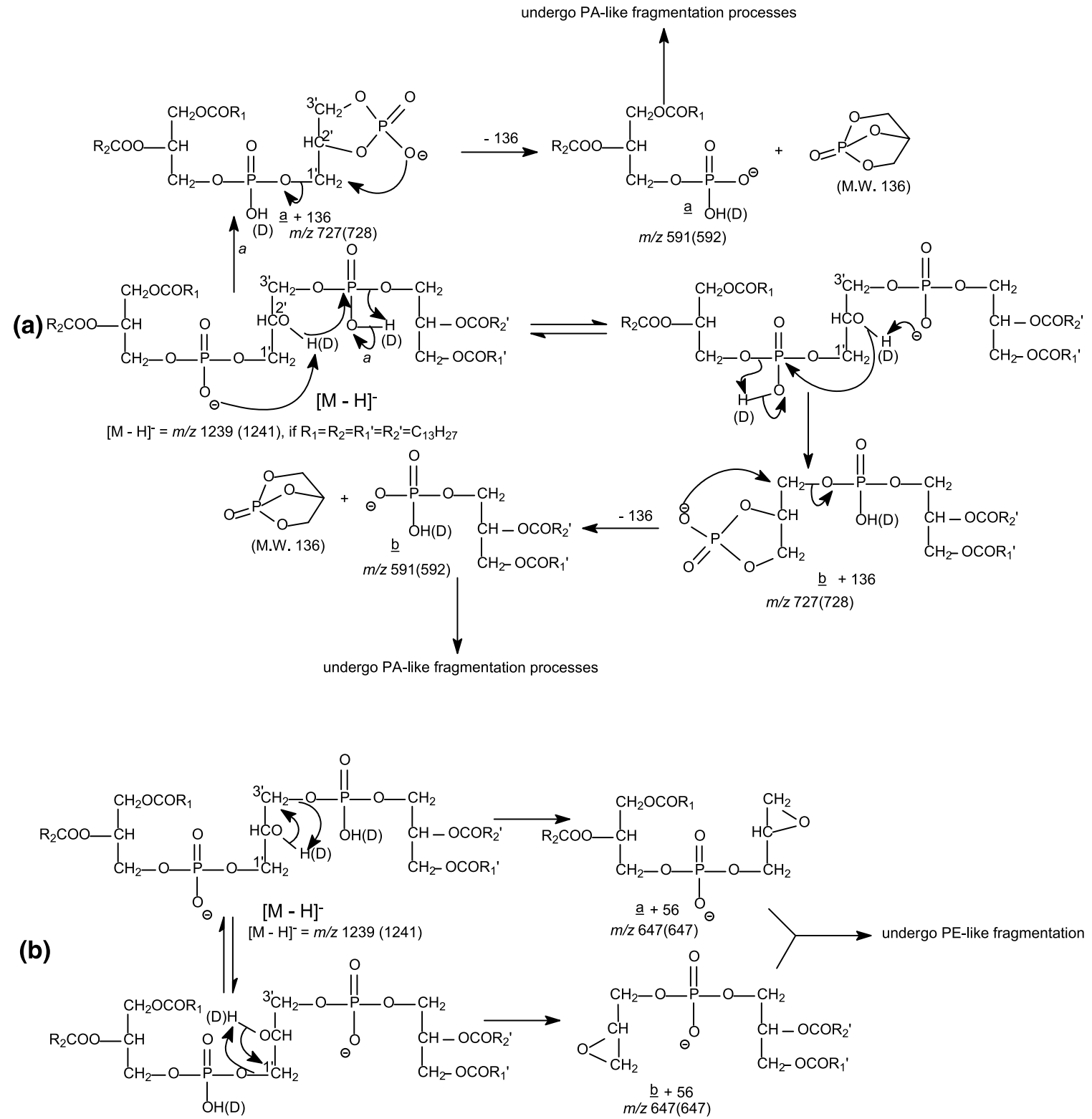

Scheme 2. The major fragmentation pathways proposed for formation (a) of the $a$ (or $b$ ), a +136 (or $b+136)$ ions and $(\mathbf{b})$ of the $a+56$ (or $b+56$ ) ions for the $[\mathrm{M}-\mathrm{H}]^{-}$ion of CL. The exchangeable hydrogens are denoted as "(D)". The $m / z$ values expected for fragment ions of (14:0/14:0)(14:0/14: $0)-C L$ and $d_{2}-(14: 0 / 14: 0)(14: 0 / 14: 0)-C L$ (in parentheses) are shown.

substituents attached. The $1^{\prime}$-phosphate site attacks on the $C(2 A)$ and results in ions of $m / z 1093(673 \times 2-253)$ and $m / z 253$ (16:1-carboxylate anion), simultaneously; while the attack on $\mathrm{C}(1 \mathrm{~A})$ resulting in ions of $\mathrm{m} / \mathrm{z} 1091$ $(673 \times 2-255)$ and 255 (16:0-carboxylate anion). The nucleophilic attack of the 3 '-phosphate anionic site on $\mathrm{C}(2 \mathrm{~B})$ and $\mathrm{C}(1 \mathrm{~B})$ gives rise to the similar ions (Scheme 1). The $\mathrm{m} / \mathrm{z} 1093$ ion is more abundant than the $\mathrm{m} / \mathrm{z} 1091$ ion and the $\mathrm{m} / \mathrm{z} 253$ ion is also more abundant than the $\mathrm{m} / \mathrm{z} 255$ ion in the spectrum. This is consistent with the notion that the mechanisms underlying the fragmentation processes for the gas-phase ions of $[\mathrm{M}-2 \mathrm{H}]^{2-}$ are similar to those observed for the $[\mathrm{M}-\mathrm{H}]^{-}$ions of $\mathrm{PE}$, and results in a greater abundance of $\mathrm{R}_{2} \mathrm{CO}_{2}{ }^{-}$(or
$\mathrm{R}_{2}, \mathrm{CO}_{2}^{-}$) than of $\mathrm{R}_{1} \mathrm{CO}_{2}^{-}$(or $\mathrm{R}_{1}, \mathrm{CO}_{2}^{-}$). This is attributable to the fact that the fragmentation processes leading to the ion formation are sterically more favorable at $s n-2$ than at'sn-1922-26]. The 'oss of the fatty acyl'substituent at $s n-2$ or at $s n-2^{\prime}$ as fatty acyl ketene leads to a doubly-charged fragment ion at $m / z 555.5(673.5 \times 2-$ 236)/2, which is more abundant than the $\mathrm{m} / z 554.5(2 \times$ 673.5 - 238)/2 ion, a doubly-charged fragment ion arising from the similar loss at $s n-1$ or at $s n-1^{\prime}$. The charge states of the above two ions are confirmed by the tandem mass spectrum of the same ions obtained with a Q-TOF instrument (data not shown), which provides sufficient resolution to show the charge state. This preferential formation of the ions reflecting the ketene 

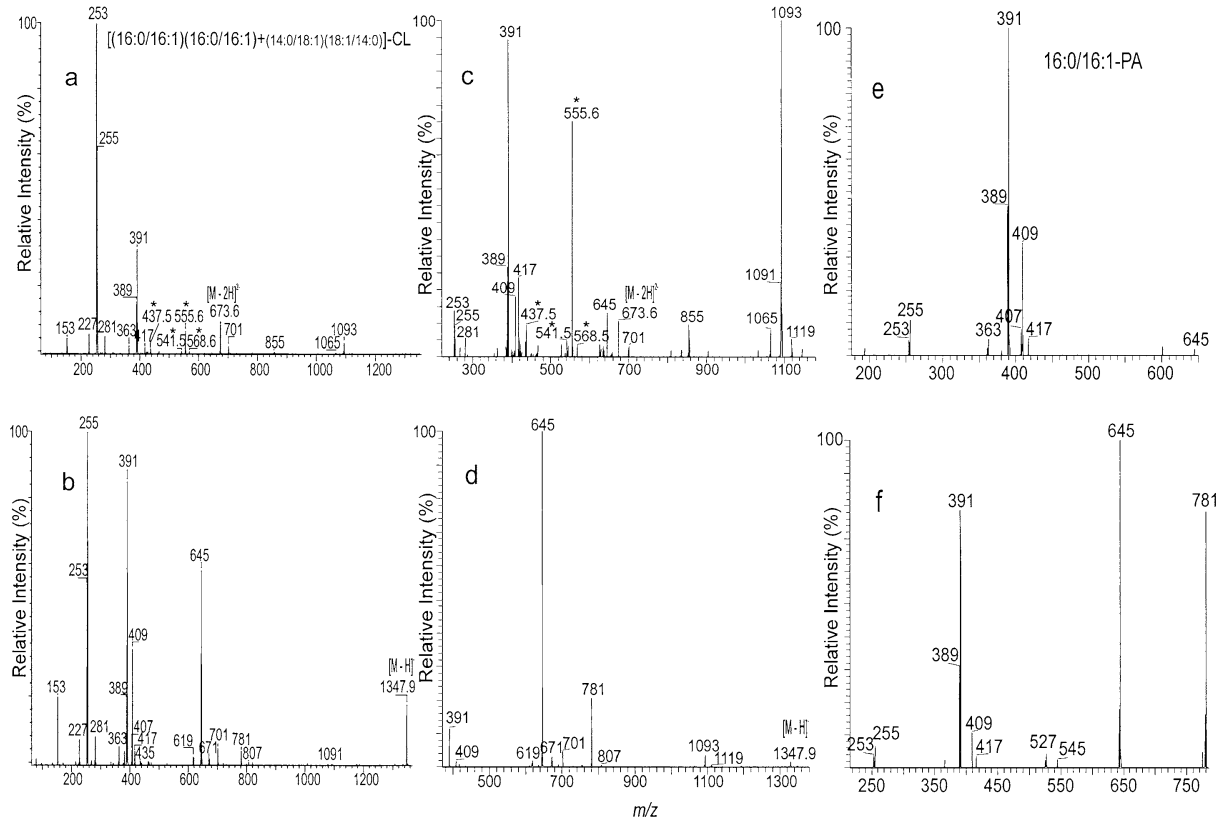

Figure 4. The tandem quadrupole product-ion spectra of the $[\mathrm{M}-2 \mathrm{H}]^{2-}$ ion at $m / z 673.6(\mathbf{a})$, and of the $[\mathrm{M}-\mathrm{H}]^{-}$ion at $m / z 1347(\mathbf{b}) ;\left(\mathbf{c}\right.$ and (d) are the IT MS'2-spectra of the $[\mathrm{M}-2 \mathrm{H}]^{2-}$ ion at $\mathrm{m} / \mathrm{z} 673.6$ (c), and of the $[\mathrm{M}-\mathrm{H}]^{-}$ion at $\mathrm{m} / \mathrm{z} 1347$ (d) from bacterium Salmonella typhimurium; (e and $\mathbf{f}$ ) are the IT MS ${ }^{3}$-spectra of $m / z 645(1347 \rightarrow 645)(\mathbf{e})$, and $m / z 781(1347 \rightarrow 781)(\mathbf{f})$. The structural assignments of the major (16:0/16:1)(16:0/16:1)-CL species along with a minor (14:0/18:1)(18:1/14:0)-CL isomer are supported by the various tandem mass spectra shown above.
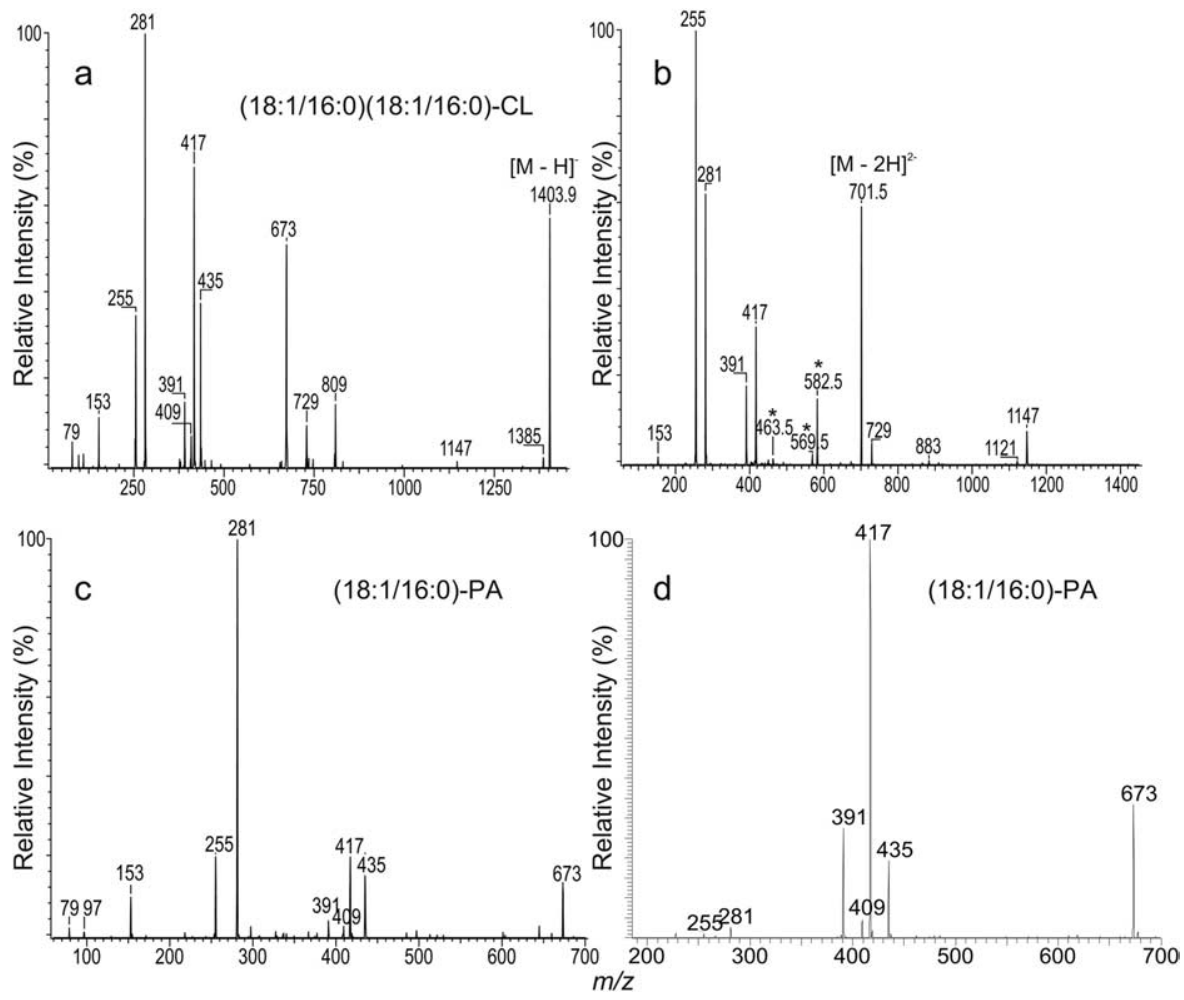

Figure 5. The tandem quadrupole mass spectra of (a) the $[\mathrm{M}-\mathrm{H}]^{-}$ion at $\mathrm{m} / z 1403$ and (b) the [M $-2 \mathrm{H}]^{2-}$ ion at $\mathrm{m} / z 701.5$ from cardiolipin mixture isolated from Mycobacterium bovis. Both the product-ion spectrum of $\mathrm{m} / \mathrm{z} 673$ (c) from source CAD and the IT MS ${ }^{3}$-spectrum of $\mathrm{m} / \mathrm{z} 673(1403 \rightarrow$ 673) (d) identify the symmetric 18:1/16:0-PA moiety of the molecule and lead to identify the (18:1/16:0)(18:1/16:0)-CL structure. 

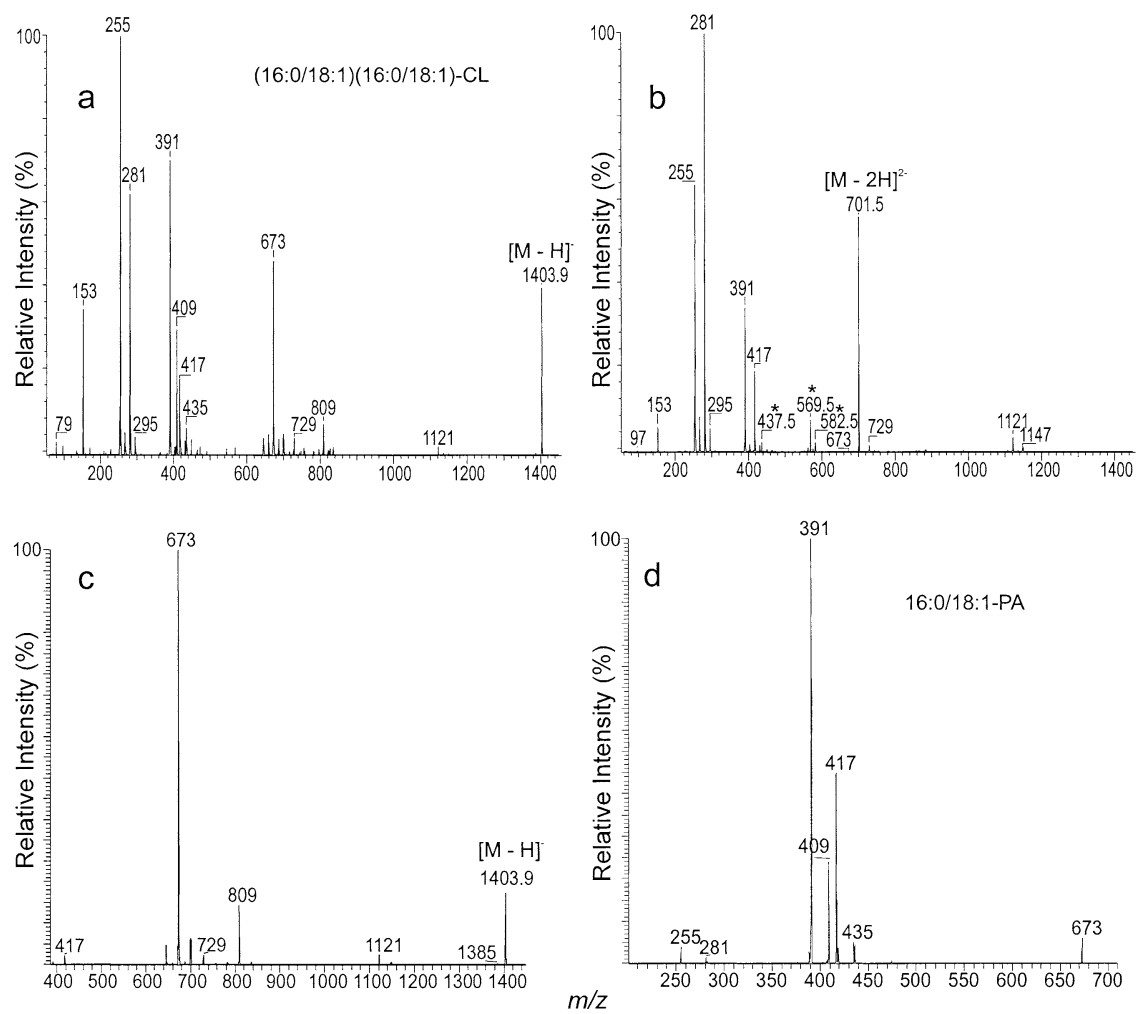

Figure 6. The tandem quadrupole mass spectra of (a) the $[\mathrm{M}-\mathrm{H}]^{-}$ion at $\mathrm{m} / z 1403$ and (b) the $[\mathrm{M}$ $-2 \mathrm{H}]^{2-}$ ion at $m / z 701.5$, and (c) the IT $\mathrm{MS}^{2}$-spectrum of the $[\mathrm{M}-\mathrm{H}]^{-}$ion at $\mathrm{m} / z 1403$ from the cardiolipin mixture isolated from bacterium Salmonella typhimurium. The IT MS ${ }^{3}$-spectrum of the $\mathrm{m} / \mathrm{z}$ $673(1403 \rightarrow 673)$ ion $(\mathbf{d})$ is identical to that arising from 16:0/18:1-PA. The assignment of the major

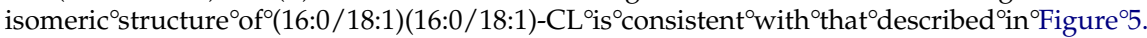

loss at $s n-2$ (or $\left.s n-2^{\prime}\right)$ over that at $s n-1$ (or $\left.s n-1^{\prime}\right)$ is also consistent with the concept as described earlier and permits structural determination of complex CL molecules, including configuration isomer and positional isomers as described later. The IT MS'-spectrum of the $[\mathrm{M}-2 \mathrm{H}]^{2-}$ ions at $\mathrm{m} / \mathrm{z} 673.5$ (Panel c) contains ions

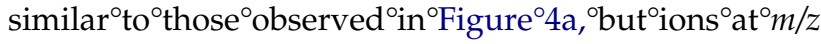
1093 and 555.6 are among the most prominent and the carboxylate anions at $\mathrm{m} / \mathrm{z} 253$ and 255 are of low abundance. This is in accord with the results observed for (14:0/14:0)(14:0/14:0)-CL ${ }^{\circ}$ (Figure $\left.2 a\right)$.

The product-ion spectra of the $[\mathrm{M}-\mathrm{H}]^{-}$ion at $m / z$ 1347 obtained with a TSQ instrument (Panel b) and with an IT instrument (Panel d) contain ions at $\mathrm{m} / \mathrm{z}$ $645(a$ and $b), 701[(a+56)$ and $(b+56)]$, and $781[(a$ $+136)$ and $(b+136)]$, resulting from the fragmentation processes involving the exchangeable hydrogens as described earlier (Scheme 2), and these ions are more prominent $^{\circ}$ in $^{\circ}$ the ${ }^{\circ} \mathrm{IT}^{\circ} \mathrm{MS}^{2}$-spectrum ${ }^{\circ}$ (Figure ${ }^{\circ} 4 \mathrm{~d}$ ). ${ }^{\circ}$ The MS $^{3}$-spectrum ${ }^{\circ}$ of $^{\circ}$ the $\mathrm{m} / \mathrm{z} 645^{\circ}$ ion $^{\circ}\left(1347^{\circ} \rightarrow 645\right)^{\circ}$ (Figure $4 \mathrm{e})^{\circ}$ is ${ }^{\circ}$ identical ${ }^{\circ}$ to ${ }^{\circ}$ that ${ }^{\circ}$ arising ${ }^{\circ}$ from ${ }^{\circ}$ the ${ }^{\circ}\left[\mathrm{M}^{\circ}-{ }^{\circ} \mathrm{H}\right]^{-}{ }^{\circ}$ ion ${ }^{\circ}$ of 16:0/16:1-PA, which contains major fragment ions at $\mathrm{m} / \mathrm{z} 391$ and 389 arising from loss of the palmitoleic acid (16:1) at $s n-2$ and loss of the palmitic acid (16:0) at $s n-1$, respectively ${ }^{\circ}[23]^{\circ}{ }^{\circ}$ This $^{\circ}$ confirms $^{\circ}$ assignment ${ }^{\circ}$ of ${ }^{\circ}$ the ${ }^{\circ}(16$ : 0/16:1)(16:0/16:1)-CL structure. The $\mathrm{MS}^{3}$-spectrum of

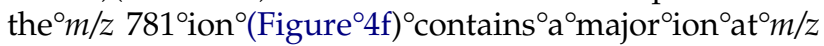

645 and fragment ions similar to those observed in the $\mathrm{MS}^{3}$-spectrum of $\mathrm{m} / \mathrm{z} 645$, indicating that $\mathrm{m} / \mathrm{z} 781$ is precursor ion of $m / z 645$ and undergoes further dissociation to $\mathrm{m} / \mathrm{z} 645(781$ - 136) via neutral loss of a stable tricyclic glycerophosphate ester (136 Da), similar to that described earlier.

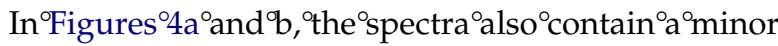
set of the carboxylate anions at $\mathrm{m} / \mathrm{z} 281$ (18:1) and 227 (14:0), indicating the presence of an isobaric structure consisting of 18:1- and 14:0-fatty acyl substituents. The results are in accord with the observation of $\mathrm{m} / \mathrm{z} 1119$ $(673 \times 2-227)$ and $m / z 1065(673 \times 2-281)$ ions in the Figure $^{\circ} 4 \mathrm{c},{ }^{\circ}$ probably ${ }^{\circ}$ arising ${ }^{\circ}$ from ${ }^{\circ} \mathrm{a}^{\circ}(14: 0 / 18: 1)(18: 1 / 14$ : $0)$-CL [or a (18:1/14:0)(14:0/18:1)-CL] isomer. This speculation is based on the fact that the two ions are nearly equal abundance. The ions at $\mathrm{m} / \mathrm{z} 281$ and 227 are also equally abundant in the product-ion spectra of both the $\left[\mathrm{M}^{\circ}-{ }^{\circ} \mathrm{H}\right]^{-}$ion $^{\circ} a^{\circ} \mathrm{m} / z 1347^{\circ}$ (Figure $\left.{ }^{\circ} 4 \mathrm{a}^{\circ}\right)^{\circ}$ and ${ }^{\circ}{ }^{\circ}{ }^{\circ}{ }^{\circ}$ the ${ }^{\circ}\left[\mathrm{M}^{\circ}-\right.$ $2 \mathrm{H}]^{2-}{ }^{\circ}$ ion $^{\circ}{ }^{\circ}{ }^{\circ} \mathrm{m} / z$ 673.6 ${ }^{\circ}$ (Figure $4 \mathrm{~b}$ ). The $^{\circ}$ structure ${ }^{\circ}$ of $^{\circ}$ this isomer is further recognized by the observation of the ions at $m / z 417(645-228)$ and $m / z 363(645-282)$, arising from losses of 14:0- and 18:1-fatty acids, respectively, in the $\mathrm{MS}^{3}$-spectrum of the $\mathrm{m} / \mathrm{z} 645$ ion $(1345 \rightarrow$ $645)^{\circ}\left(\right.$ Figure $\left.^{\circ} 4 \mathrm{e}\right) .^{\circ}{ }^{\circ}$ The $^{\circ}$ abundances ${ }^{\circ}$ of $^{\circ}$ the ${ }^{\circ}$ ions ${ }^{\circ}$ at ${ }^{\circ} \mathrm{m} / z 417$ and at 363 are nearly identical, indicating the presence of both a 18:1/14:0-PA and a 14:0/18:1-PA isomer.

The observation in the differences in abundances of the 

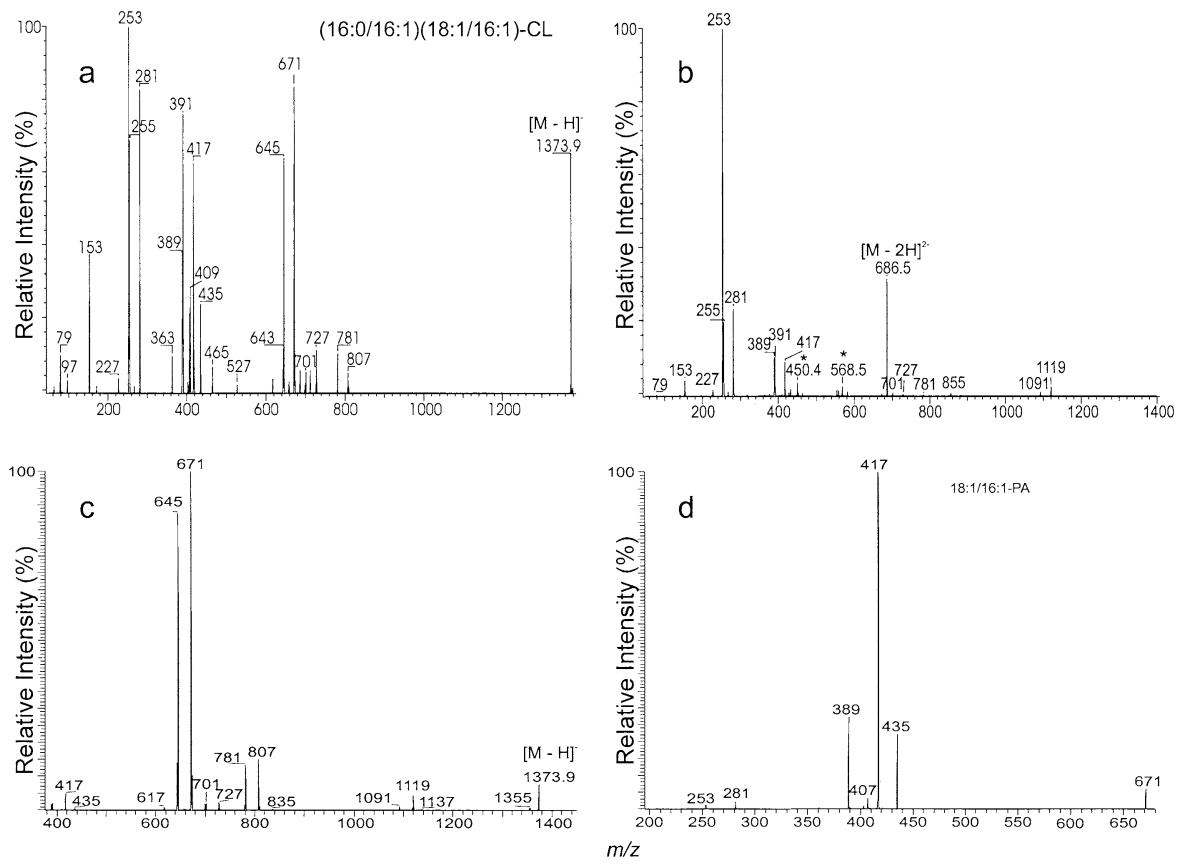

Figure 7. The tandem quadrupole mass spectra of the $[\mathrm{M}-\mathrm{H}]^{-}$ion at $\mathrm{m} / \mathrm{z} 1373(\mathbf{a})$ and of the $[\mathrm{M}-$ $2 \mathrm{H}]^{2-}$ ion at $m / z 686.5$ (b) from cardiolipin mixture isolated from bacterium Salmonella typhimurium. The IT MS'2-spectrum of the $[\mathrm{M}-\mathrm{H}]^{-}$ion at $m / z 1373$ is shown in (c), and the $\mathrm{MS}^{3}$-spectrum of the $m / z 671$ ion $(1373 \rightarrow 671)$ is shown in $(\mathbf{d})$. The information from these spectra combined identifies the major (16:0/16:1)(18:1/16:1)-CL structure.

carboxylate anions leading to the structural characterization of $\mathrm{CL}$ is further demonstrated by the product-ion spectra of the $\left[\mathrm{M}^{\circ}-\mathrm{H}\right]^{-}$ion $^{\circ} \mathrm{t} m / z 1403^{\circ}$ (Figure 5 a) ${ }^{\circ}$ and the $\left[\mathrm{M}^{\circ}-2 \mathrm{H}\right]^{2-}{ }^{\circ}$ ion $^{\circ} \mathrm{at}^{\circ} \mathrm{m} / \mathrm{z} 701.6^{\circ}$ (Figure $5 \mathrm{~b}$ ), ${ }^{\circ}$ observed ${ }^{\circ}$ for $^{\circ}$ the lipid extract from Mycobacterium bovis BCG. The $\mathrm{m} / \mathrm{z} 281$ ion (18:1) is more abundant than the $m / z 255$ ion (16:0) in the ${ }^{\circ}$ product-ion $^{\circ}$ spectrum $^{\circ}$ of ${ }^{\circ} \mathrm{m} / \mathrm{z} 1403^{\circ}$ (Figure $^{\circ} 5 \mathrm{a}$ ), ${ }^{\circ}$ a singly-charged ion. However, the abundances of the two ions are reversed in the product-ion spectrum of the $[\mathrm{M}-$

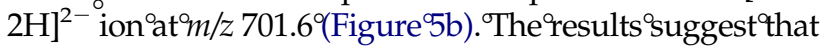
the 18:1- and 16:0-fatty acyl substituents probably reside at $s n-1$ (or $\left.s n-1^{\prime}\right)$ and $s n-2$ (or $\left.s n-2^{\prime}\right)$, respectively. This assignment is further supported by observation of a greater abundance of the $\mathrm{m} / \mathrm{z} 1147(701 \times 2-255)$ ion than the $\mathrm{m} / \mathrm{z}$ $1121(701 \times 2-281)$ ion and a greater abundance of the $\mathrm{m} / \mathrm{z} 582.6$ ion $(701.6 \times 2-238) / 2$ than the $\mathrm{m} / \mathrm{z} 569.6$ (701.6 $\times 2-264) / 2$ ion in the product-ion spectrum of the [M $2 \mathrm{H}]^{2{ }^{\circ}}$ ion $^{\circ}$ at $^{\circ} \mathrm{m} / \mathrm{z} 701.6^{\circ}$ (Figure ${ }^{\circ} 5 \mathrm{~b}$ ). ${ }^{\circ} \mathrm{In}^{\circ}$ Figure $^{\circ} 5 \mathrm{a}^{\circ},{ }^{\circ}$ the spectrum contains the prominent ion set of $m / z 673(a \& b)$, $729[(a+56)$ and $(b+56)]$ and $809[(a+136)$ and $(b+$ 136)]. The identities and positions of the fatty acyl substituents are recognized by the source CAD product-ion spectrum ${ }^{\circ}$ of ${ }^{\circ} \mathrm{m} / \mathrm{z} 673^{\circ}$ (Figure ${ }^{\circ} \mathrm{c}$ ), ${ }^{\circ}$ which ${ }^{\circ}$ is ${ }^{\circ}$ identical ${ }^{\circ}$ to ${ }^{\circ}$ that of 18:1/16:0-PA obtained with a triple quadrupole instrument. The IT MS ${ }^{2}$-spectrum of the $\mathrm{m} / \mathrm{z} 673$ ion $(1403 \rightarrow$ $673)^{\circ}$ (Figure $\left.{ }^{\circ} 5 \mathrm{~d}\right)^{\circ}$ is $^{\circ}$ also $^{\circ}$ identical ${ }^{\circ}$ to $^{\circ}$ the ${ }^{\circ} \mathrm{MS}^{3}$-spectrum ${ }^{\circ}$ of 18:1/16:0-PA, which is featured by that the $\mathrm{m} / \mathrm{z} 417$ ion (673 - 256) arising from loss of 16:0-acid is more abundant than $\mathrm{m} / \mathrm{z} 391$ (673 - 282, arising from loss of 18:1-acid; and that the $m / z 435$ ion $(673-238)$ arising from loss of 16:0-ketene is more abundant than $\mathrm{m} / \mathrm{z} 409$ (673 - 264), arising from loss of 18:1-ketene. The $\mathrm{MS}^{2}$-spectra in combination with the $\mathrm{MS}^{3}$-spectra described above suggest that the compound represents a $(18: 1 / 16: 0)(18: 1 / 16: 0)-C L$ structure.

In the lipid extract from bacterium Salmonella typhimurium, the $\mathrm{m} / \mathrm{z} 255$ ion is more abundant than the $\mathrm{m} / \mathrm{z}$ 281 ion in the product-ion spectrum of the $[\mathrm{M}-\mathrm{H}]^{-}$ion at $m / z 1403^{\circ}$ (Figure $6 \mathrm{a}$ ), ${ }^{\circ}$ while the abundances ${ }^{\circ}$ of ${ }^{\circ}$ the ${ }^{\circ}$ two ions are reversed in the product-ion spectrum of the [M $\left.{ }^{\circ} 2 \mathrm{H}\right]^{2-}{ }^{\circ}$ ion $^{\circ}$ at ${ }^{\circ} \mathrm{m} / \mathrm{z} 701.6^{\circ}$ (Figure ${ }^{\circ} 6 \mathrm{~b}$ ). ${ }^{\circ}{ }^{\circ}$ These ${ }^{\circ}$ results ${ }^{\circ}$ are opposite to those observed for $(18: 1 / 16: 0)(18: 1 / 16$ : 0 )-CL ${ }^{\circ}$ as $^{\circ}$ shown $^{\circ}{ }^{\circ}{ }^{\circ}$ Figure $^{\circ} 5 a^{\circ}$ and ${ }^{\circ} \mathrm{b}$. ${ }^{\circ}$ The ${ }^{\circ} \mathrm{MS}^{2}$-spectra ${ }^{\circ}$ of the $[\mathrm{M}-\mathrm{H}]^{-}$ion at $\mathrm{m} / \mathrm{z} 1403$ obtained with a TSQ

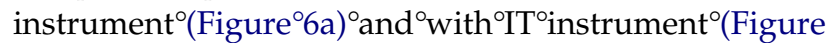
6c) ${ }^{\circ}$ also $^{\circ}$ contain $^{\circ}$ the $^{\circ}$ ion $^{\circ}$ set $^{\circ}$ of $^{\circ} \mathrm{m} / z \quad 673,{ }^{\circ} 729,{ }^{\circ}$ and ${ }^{\circ} 809$ similar ${ }^{\circ}$ to $^{\circ}$ those $^{\circ}$ observed $^{\circ}$ in $^{\circ}{ }^{\circ}$ Figure $^{\circ} 5 \mathrm{a},{ }^{\circ}$ indicating ${ }^{\circ}$ that the compound may represent a positional isomer. The identities and positions of the fatty acyl substituents are further recognized by the $\mathrm{MS}^{3}$-spectrum of $\mathrm{m} / \mathrm{z} 673$ $\left(1403^{\circ} \rightarrow 673\right)^{\circ}\left(\right.$ Figure $\left.^{\circ} 6 \mathrm{~d}\right){ }^{\circ}{ }^{\circ}$ which $^{\circ}$ is ${ }^{\circ}$ identical ${ }^{\circ}$ to ${ }^{\circ}$ that arising from 16:0/18:1-PA and clearly reveals the structure of $(16: 0 / 18: 1)(16: 0 / 18: 1)-C L$.

\section{Structural Characterization of Cardiolipins Containing Different Diacylglycerol Moieties by CAD Product-Ion Spectra of the $[\mathrm{M}-\mathrm{H}]^{-}$ and $[\mathrm{M}-2 \mathrm{H}]^{2-}$ Ions}

The characterization of cardiolipin consisting of two various diacylglycerol moieties is illustrated by the 

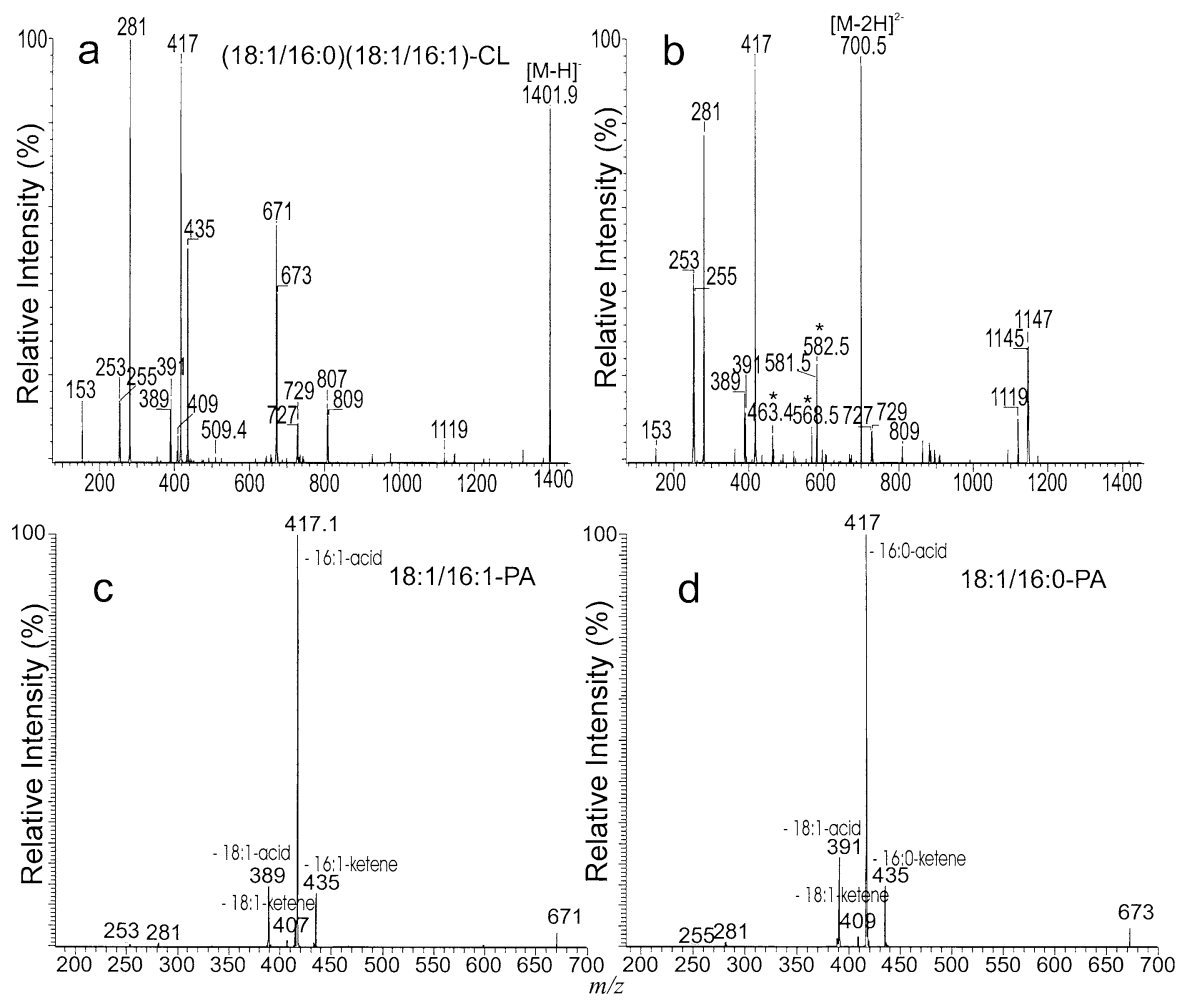

Figure 8. The tandem quadrupole mass spectra of the $[\mathrm{M}-\mathrm{H}]^{-}$ion at $\mathrm{m} / \mathrm{z} 1401$ (a) and the [M $2 \mathrm{H}]^{2-}$ ion at $\mathrm{m} / \mathrm{z} 700.5$ (b) from cardiolipin mixture isolated from Mycobacterium bovis. The IT MS $^{3}$-spectra of $(\mathbf{c}) \mathrm{m} / \mathrm{z} 671(1401 \rightarrow 671)$, and (d) $\mathrm{m} / \mathrm{z} 673(1401 \rightarrow 673)$ confirm the 18:1/16:0-PA and 18:1/16:1-PA structures, respectively. The assignment of the (18:1/16:0)(18:1/16:1)-CL structure is also determined by the fact that the $\mathrm{m} / \mathrm{z} 671$ ion is more abundant than the $\mathrm{m} / \mathrm{z} 673$ ion.

product-ion spectra of the $\mathrm{m} / \mathrm{z} 1373$ ion obtained with a TSQ $^{\circ}$ instrument ${ }^{\circ}\left(\text { Figure }^{\circ} 7 \mathrm{a}\right)^{\circ}$ and $^{\circ}$ with $^{\circ}$ an $^{\circ}$ ITMS $^{\circ}$ (Figure $7 \mathrm{~b}) .{ }^{\circ}$ Both ${ }^{\circ}$ spectra ${ }^{\circ}$ contain $\left.^{\circ}\right)^{\circ} e^{\circ}{ }^{\circ}{ }^{\circ}{ }^{\circ}$ sets $^{\circ}$ of ${ }^{\circ} \mathrm{m} / \mathrm{z} 671^{\circ}(a$ ion), $727(a+56), 807(a+136)$ and of $m / z 645(b), 701(b+$ 56), $781(b+136)$. The $\mathrm{MS}^{3}$-spectrum of the $m / z 645$ ion $(1373 \rightarrow 645)$ (data not shown) in the latter set is identical ${ }^{\circ}$ to ${ }^{\circ}$ that ${ }^{\circ}$ observed $^{\circ}$ in $^{\circ}$ Figure $^{\circ} 4 \mathrm{e}^{\circ}$, suggesting ${ }^{\circ}$ a 16:0/16:1-PA configuration. The $\mathrm{MS}^{3}$-spectrum of $\mathrm{m} / \mathrm{z}$ $671^{\circ}\left(1373^{\circ} \rightarrow 671\right)^{\circ}\left(\text { Figure }^{\circ} 7 \mathrm{~d}\right)^{\circ}$ of $^{\circ}$ the $^{\circ}$ former $^{\circ}$ set $^{\circ}$ is dominated by the $\mathrm{m} / \mathrm{z} 417$ ion, arising from a 16:1-acid loss at $s n-2^{\prime}$, and the less prominent ion at $\mathrm{m} / \mathrm{z} 389$ arising from loss of the 18:1-acid at $s n-1^{\prime}$, exhibiting a 18:1/16:1-PA structure. These results indicate that the $m / z 1373$ ion probably represents a $(18: 1 / 16: 1)(16: 0 / 16$ : 1)-CL. The $\mathrm{m} / \mathrm{z} 671(\mathrm{a})$ is more abundant than $\mathrm{m} / \mathrm{z} 645 \mathrm{(b}$ ion) in the $\mathrm{MS}^{2}$-spectrum of the $[\mathrm{M}-\mathrm{H}]^{-}$ion at $\mathrm{m} / \mathrm{z}$ 1373 , consistent with the notion that cardiolipin contains ${ }^{\circ}$ two ${ }^{\circ}$ Chemically $^{\circ}$ distinct $^{\circ}$ phosphatidy $l^{\circ}$ moieties ${ }^{\circ}[2$, $\left.27,{ }^{\circ} 28\right]^{\circ}{ }^{\circ}$ The ${ }^{\circ}$ observation ${ }^{\circ}$ of ${ }^{\circ} a^{\circ}$ greater ${ }^{\circ}$ abundance ${ }^{\circ}$ of ${ }^{\circ}$ the $\mathrm{m} / \mathrm{z} 671$ ion than the $\mathrm{m} / \mathrm{z} 645$ ion may indicate that the 18:1/16:1-glycero moiety is attached to the $1^{\prime}$ position of the central glycerol. This speculation is based on the fact that the $\mathrm{H}^{+}$on the phosphate attached to $s n-3\left(\mathrm{pK}_{1}=\right.$ $2.8)$ is more acidic than that at $s n-3^{\prime}\left(\mathrm{pK}_{2^{\circ}}>7.5\right)^{\circ}[28]^{\circ}$ and the anionic charge site may more favorably reside at $s n-3^{\prime}$ phosphate and initiates the cleavage of $\mathrm{P}-\mathrm{O}$ bond via a charge-driven process with the participation of the exchangeable hydrogen as shown in Scheme 2a (route a). This fragmentation process also results in expulsion of a diacylglycerol and gives rise to an $m / z 807(a+136)$ ion, which dissociates to $m / z 671$ (a) by loss of a tricyclic glycerophosaphate ester of $136 \mathrm{Da}$ as described earlier.

The carboxylate anions were observed at $\mathrm{m} / \mathrm{z} 281$ (18:1), 255 (16:0), and 253 (16:1), and the $m / z 253$ ion is 5 -fold the abundance of $\mathrm{m} / \mathrm{z} 255$ and of $\mathrm{m} / \mathrm{z} 281$ in the product-ion spectrum of the $[\mathrm{M}-2 \mathrm{H}]^{2-}$ ion at $\mathrm{m} / \mathrm{z}$ $686.5^{\circ}$ (Figure $\left.{ }^{\circ} 7 \mathrm{~b}\right) .{ }^{\circ}$ This $^{\circ}{ }^{\circ}{ }^{\circ}{ }^{\circ}$ consistent ${ }^{\circ}$ with $^{\circ}$ the ${ }^{\circ}$ notion that the $[\mathrm{M}-2 \mathrm{H}]^{2-}$ ion at $m / z 686.5$ is a basic ion and undergoes fragmentation processes similar to those observed $^{\circ}$ for ${ }^{\circ} \mathrm{PE}^{\circ}[26],{ }^{\circ}$ resulting ${ }^{\circ}$ in $^{\circ}$ more $^{\circ}$ favorable formation of the $\mathrm{R}_{2} \mathrm{CO}_{2}{ }^{-}$(or $\mathrm{R}_{2}, \mathrm{CO}_{2}{ }^{-}$) anions than of the $\mathrm{R}_{1} \mathrm{CO}_{2}^{-}$(or $\mathrm{R}_{1}, \mathrm{CO}_{2}^{-}$) ions. The results are also consistent with the fact that the molecule consists of two palmiteoyl fatty acyl substituents, respectively residing at $s n-2$ and $s n-2^{\prime}$, and one palmitoyl residing at $s n-1$ and one oleoyl residing $s n-1^{\prime}$. In contrast, differences in the abundances among the $m / z 253,255$, and 281 ions are not substantial in the product-ion spectrum ${ }^{\circ}$ of ${ }^{\circ}$ the ${ }^{\circ}\left[\mathrm{M}^{\circ}-{ }^{\circ} \mathrm{H}\right]^{-}{ }^{\circ}$ ion at ${ }^{\circ} \mathrm{m} / z$ 1373 ${ }^{\circ}$ (Figure $\left.\% \mathrm{a}\right)$, which undergoes fragmenatations similar to those observed for PA (23). The fragmentation processes occurred to the $[\mathrm{M}-2 \mathrm{H}]^{2-}$ ion at $\mathrm{m} / \mathrm{z} 686.5$ also result in the preferential loss of the fatty acyl substituents at $s n-2$ (or $\left.s n-2^{\prime}\right)$ as ketene and leads to 

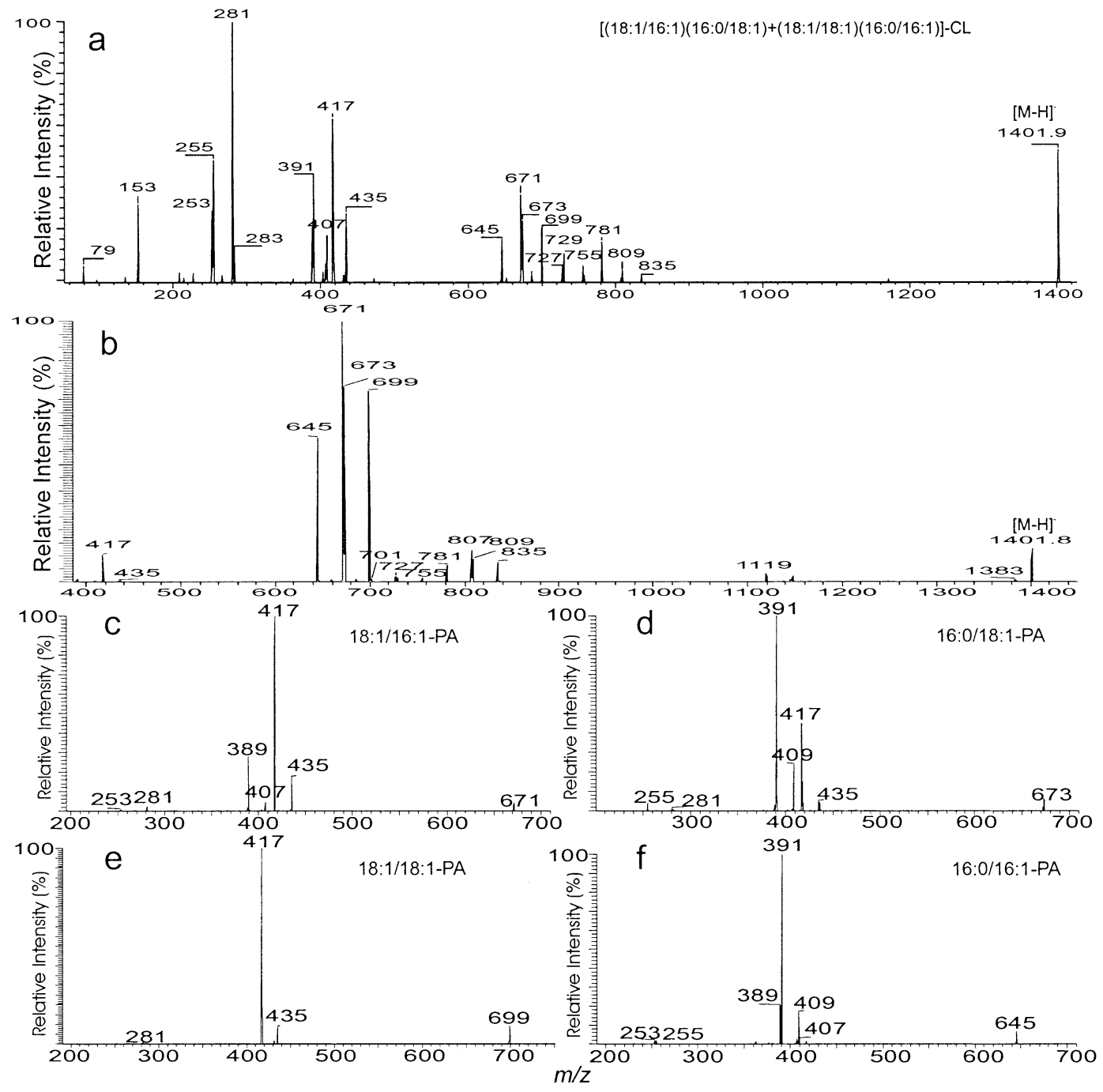

Figure 9. The tandem mass spectra of the $[\mathrm{M}-\mathrm{H}]^{-}$ions of $\mathrm{m} / \mathrm{z} 1401$ obtained with (a) a TSQ instrument, $(\mathbf{b})$ with an ITMS. The IT MS ${ }^{3}$-spectra of $\mathrm{m} / \mathrm{z} 671(1401 \rightarrow 671)(\mathbf{c}), \mathrm{m} / \mathrm{z} 673(1401 \rightarrow 673)$ $(\mathbf{d}), m / z 699(1401 \rightarrow 699)(\mathbf{e})$, and $m / z 645(1401 \rightarrow 645)(\mathbf{f})$ provide information for locating the fatty acyl substituents. The structural information from the above spectra combined suggests that the species consists of a major $(18: 1 / 16: 1)(16: 0 / 18: 1)-C L$ along with a $(18: 1 / 18: 1)(16: 0 / 16: 1)-C L$ isomer.

formation of a doubly-charged fragment ion at $\mathrm{m} / \mathrm{z}$ $568.5(686.5 \times 2-236) / 2$, arising from loss of the 16:1-fatty acyl ketene at $s n-2$ (or $\left.s n-2^{\prime}\right)$. The preferential attack of the anionic charge site on $\mathrm{C}(2 \mathrm{~A})$ [or $\mathrm{C}(2 \mathrm{~B})]$ of the glycerol also results in more favorable formation of $\mathrm{m} / \mathrm{z} 1119(686 \times 2-253)$ than of $\mathrm{m} / \mathrm{z} 1117$ $(686 \times 2-255)($ not seen) or of $\mathrm{m} / \mathrm{z} 1091(686 \times 2-$ 281) that arises from the similar attack on $C(1 \mathrm{~A})$ [or $\mathrm{C}(1 \mathrm{~B})]$, and provide information to confirm the position of fatty acyl substituents on the glycerol backbone.

The tandem quadrupole mass spectra of the $[\mathrm{M}-$

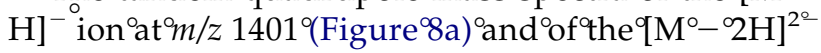
ion $^{\circ}$ at $^{\circ} \mathrm{m} / \mathrm{z} 700.5^{\circ}$ (Figure $\left.^{\circ} 8 \mathrm{~b}\right)^{\circ}$ arising $^{\circ}$ from $^{\circ}$ the ${ }^{\circ}$ lipid extract of Mycobacterium bovis BCG contain carboxylate anions at $m / z 281$ (18:1), 253 (16:1) and 255 (16:0). The structural determination is established by the observation of the ion sets of $m / z 671(a), 727(a+56)$, $807(a+136)$ and of $m / z 673(b), 729(b+56), 809(b$ $+136)$. The two ion sets reflect a 18:1/16:1- and a 18:1/16:0-phosphatidyl moiety, respectively, as evidenced by the source-CAD tandem mass spectra of $m / z 671$ and 673 (not shown), and further confirmed by ${ }^{\circ}$ the ${ }^{\circ}{ }^{\circ} \mathrm{MS}^{3^{\circ}}$-spectra ${ }^{\circ}{ }^{\circ} \mathrm{m} / \mathrm{z} 673^{\circ}\left(1401^{\circ} \rightarrow 673\right)^{\circ}$ (Figure $8 \mathrm{c})^{\circ}$ and $^{\circ} 671^{\circ}\left(1401^{\circ} \rightarrow 671\right)^{\circ}$ (Figure $8 \mathrm{~d}$ ). ${ }^{\circ}$ Since ${ }^{\circ}$ the ${ }^{\circ}$ former ion set is more abundant than the latter, a $(18: 1 / 16$ : 1)(18:1/16:0)-CL structure can be easily assigned. In the product-ion spectrum of the $[\mathrm{M}-2 \mathrm{H}]^{2-}$ ion at $\mathrm{m} / \mathrm{z} 700.5^{\circ}$ (Figure $\left.{ }^{\circ} 8 \mathrm{~b}\right){ }^{\circ}$, the ${ }^{\circ} \mathrm{m} / \mathrm{z} 1147^{\circ}\left(700^{\circ} \times{ }^{\circ} 2^{\circ}-{ }^{\circ} 253\right)$ and $1145(700 \times 2-255)$ ions, reflecting the $\mathrm{R}_{2} \mathrm{CO}_{2}{ }^{-}$ and $\mathrm{R}_{2}, \mathrm{CO}_{2}{ }^{-}$losses, respectively, are more abundant than $m / z 1119(700 \times 2-281)$, reflecting the $\mathrm{R}_{1} \mathrm{CO}_{2}{ }^{-}$ (or $\mathrm{R}_{1}, \mathrm{CO}_{2}{ }^{-}$) loss. The doubly-charged ions at $\mathrm{m} / \mathrm{z}$ $582.5(700.5 \times 2-236) / 2$ and at $\mathrm{m} / \mathrm{z} 581.5(700.5 \times 2$ - 238)/2 arising from the respective 16:1- and 16:0acyl losses as ketenes are also more abundant than 


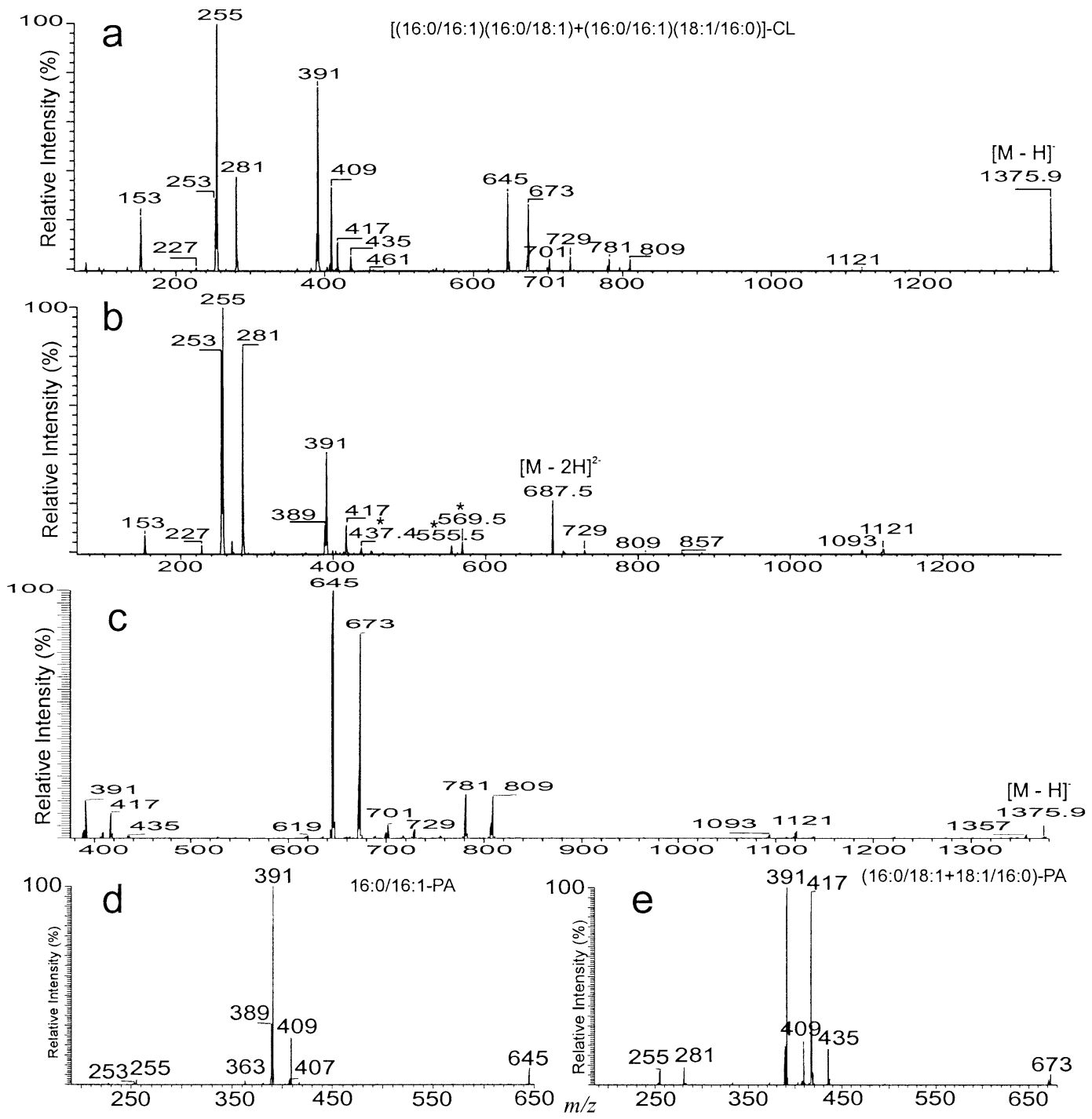

Figure 10. The product-ion spectra of (a) the $\left[\mathrm{M}-\mathrm{H}^{-}\right.$ion at $m / z 1375$ and $(\mathbf{b})$ the $[\mathrm{M}-2 \mathrm{H}]^{2-}$ ion at $m / z 687.5$ obtained with a TSQ instrument. The IT $\mathrm{MS}^{2}$-spectrum of the $[\mathrm{M}-\mathrm{H}]^{-}$ions at $\mathrm{m} / \mathrm{z} 1375$ is shown in (c), which contains ions similar to those observed in (a) and (b), but carboxylate anions are absent because of low-mass cutoff. The IT MS ${ }^{3}$-spectrum of $m / z 645(1375 \rightarrow 645)$ (d) is typical of 16:0/16:1-PA, and the $\mathrm{MS}^{3}$-spectrum of $\mathrm{m} / \mathrm{z} 673(1375 \rightarrow 673)(\mathbf{e})$ is probably a mixed spectra consisting of both a 16:0/18:1- and an 18:1/16:0-PA. The combined information suggests that the molecules are isomers of (16:0/16:1)(16:0/18:1)-CL and (16:0/16:1)(18:1/16:0)-CL.

$m / z 568.5(700.5 \times 2-264) / 2$, arising from loss of a 18:1-acyl moiety as a ketene. These results further confirm the assignment of the positions of the fatty acyl substituents of the molecule.

\section{Structural Characterization of Cardiolipin Molecular Species with Multiple Isobaric Isomers}

Structural characterization of cardiolipins of biological origin is often complicated by numerous homologs ${ }^{\circ}$ that $^{\circ}$ consist $^{\circ}$ of $^{\circ}$ various $^{\circ}$ isomers ${ }^{\circ}$ (Figure 1$) .{ }^{\circ}$ For examples, the product-ion spectra of $\mathrm{m} / z 1401$ ions obtained ${ }^{\circ}$ with $^{\circ} \mathrm{a}^{\circ} \mathrm{TSQ}^{\circ}{ }^{\circ}$ instrument $^{\circ}$ (Figure ${ }^{\circ} 9 \mathrm{a}^{\circ}{ }^{\circ}$ and ${ }^{\circ}$ with an $^{\circ}$ ITMS $^{\circ}$ (Figure ${ }^{\circ} 9$ b $^{\circ}{ }^{\circ}$ arising $^{\circ}$ from $^{\circ}$ the $^{\circ}$ lipid ${ }^{\circ}$ extract $^{\circ}$ of bacterium Salmonella typhimurium contain prominent ion set of $m / z 671(a), 727(a+56)$, and $807(a+136)$, along with the ion set of $m / z 673(b), 729(b+56), 809$ $(b+136)$. The $m / z 671$ is more abundant than $m / z 673$, suggesting the presence of the $(18: 1 / 16: 1)(16: 0 / 18$ : $1)-C L$ isomer. This structure is further confirmed by the ${ }^{\circ} \mathrm{MS}^{3^{\circ}}$-spectra ${ }^{\circ}$ of $^{\circ} \mathrm{m} / z 671^{\circ}\left(1401^{\circ} \rightarrow 671,{ }^{\circ}\right.$ Figure $\left.^{\circ} 9 \mathrm{c}\right)$ and $^{\circ} \mathrm{m} / \mathrm{z} 673^{\circ}\left(1401^{\circ} \rightarrow 673{ }^{\circ}\right.$ Figure $\left.^{\circ} 9 \mathrm{~d}\right),{ }^{\circ}$ which $^{\circ}$ are equivalent to $18: 1 / 16: 1-\mathrm{PA}$ and 16:0/18:1-PA, respectively. $^{\circ}$ The $^{\circ}$ tandem $^{\circ}$ mass $^{\circ}$ spectra $^{\circ}\left(\right.$ Figure $^{\circ} 9 \mathrm{a}^{\circ}$ and $\left.^{\circ} \mathrm{b}\right)$ also contain the ion set at $m / z 699(a), 755(a+56)$, and $835(a+136)$, along with its complementary ion set at $m / z 645(b), 701(b+56)$, and $781(b+136)$, suggesting the presence of a second isomer, probably representing a $(18: 1 / 18: 1)(16: 0 / 16: 1)-C L$. This speculation, again, is based on the findings that the $m / z 699$ ion is 
more abundant than $m / z$ 645, and further confirmed by $^{\circ}$ the ${ }^{\circ} \mathrm{MS}^{3^{\circ}}$-spectrum ${ }^{\circ}$ of ${ }^{\circ} \mathrm{m} / \mathrm{z} 699^{\circ}\left(1401^{\circ} \rightarrow 699\right.$, $^{\circ}$ Figure 9e), ${ }^{\circ}$ which $^{\circ}$ is ${ }^{\circ}$ equivalent ${ }^{\circ}$ to ${ }^{\circ} 18: 1 / 18: 1-\mathrm{PA}^{\circ}$ and $^{\circ}$ of ${ }^{\circ} \mathrm{m} / \mathrm{z}$ $645^{\circ}\left(1401^{\circ} \rightarrow 645,{ }^{\circ}\right.$ Figure $\left.^{\circ} 9 \mathrm{f}\right){ }^{\circ}$ representing ${ }^{\circ} \mathrm{a}^{\circ} 16: 0 / 16: 1$ PA. Structural determination of complex CL containing multiple isomeric structures are further demonstrated by the product-ion spectra of the $[\mathrm{M}-\mathrm{H}]^{-}$ ion $^{\circ}{ }^{\circ} \mathrm{o}^{\circ} \mathrm{m} / \mathrm{z} 1375^{\circ}$ (Figure $\left.{ }^{\circ} 10 \mathrm{a}\right)^{\circ}$ and $^{\circ}$ the ${ }^{\circ}\left[\mathrm{M}^{\circ}-{ }^{\circ} 2 \mathrm{H}\right]^{2{ }^{\circ}}{ }^{\circ}$ ion at $^{\circ} \mathrm{m} / \mathrm{z} 687.5^{\circ}$ (Figure ${ }^{\circ} 10 \mathrm{~b}$ ) ${ }^{\circ}$ observed ${ }^{\circ}{ }^{\circ}{ }^{\circ}$ the lipid $^{\circ}$ extract from bacterium Salmonella typhimurium. The two spectra contain the carboxylate anions at $m / z 281,255$, and 253 , reflecting the 18:1, 16:0 and 16:1-fatty acyl substituents, respectively. The tandem mass spectra of the $m / z 1375$ ion obtained with an TSQ instrument (Figure $\left.^{\circ} 10 \mathrm{a}\right)^{\circ}$ and $^{\circ}$ ITMS $^{\circ}\left(\text { Figure }^{\circ} 10{ }^{\circ}\right)^{\circ}$ contain $^{\circ}$ two $^{\circ}$ ion sets observed at $m / z 645(a), 701(a+56)$ and $781(a+$ 136), and at $m / z 673(b), 729(b+56)$ and $809(b+136)$. The $^{\circ}$ IT $^{\circ} \mathrm{MS}^{3^{\circ}}{ }^{-}$spectra ${ }^{\circ}$ of $^{\circ} \mathrm{m} / z 645^{\circ}\left(1375^{\circ} \rightarrow 645\right)^{\circ}$ (Figure 10d $)^{\circ}$ clearly $^{\circ}$ identify $^{\circ}$ the ${ }^{\circ} 16: 0 / 16: 1-\mathrm{PA}^{\circ}$ moiety, $^{\circ}$ as supported by observation of the preferential loss of the 16:1- over the 16:0-fatty acyl moiety. However, ions at $m / z 417(673-256)$ and $391(673-282)$, corresponding to losses of 16:0- and 18:1-fatty acids, respectively, are nearly equal abundance in the IT MS $^{3^{\circ}}$-spectrum ${ }^{\circ}$ of $^{\circ} \mathrm{m} / \mathrm{z} 673^{\circ}\left(1375^{\circ} \rightarrow 673\right)^{\circ}\left(\right.$ Figure $\left.^{\circ} 10 \mathrm{e}\right)$, indicating that the $\mathrm{m} / \mathrm{z} 673$ ion probably represents isomers of 16:0/18:1-PA and 18:1/16:0-PA. This speculation is based on the $\mathrm{MS}^{3}$-spectra of the $\mathrm{m} / \mathrm{z} 673$ ions observed $^{\circ}{ }^{\circ}{ }^{\circ}$ Figure $^{\circ} 8 \mathrm{f}^{\circ}$ arising ${ }^{\circ}$ from ${ }^{\circ} 18: 1 / 16: 0-\mathrm{PA},{ }^{\circ}$ and in ${ }^{\circ}$ Figure ${ }^{\circ} 9 \mathrm{~d}^{\circ}$ arising ${ }^{\circ}$ from ${ }^{\circ}{ }^{\circ} 16: 0 / 18: 1-\mathrm{PA}{ }^{\circ}$ isomer. ${ }^{\circ}$ The speculation is also consistent with the fact that ions at $\mathrm{m} / \mathrm{z} 255$ and 281 are also nearly equally abundant (Figure $\left.{ }^{\circ} 10 \mathrm{e}\right) .^{\circ}{ }^{\circ}$ The $^{\circ}$ results $^{\circ}$ suggest ${ }^{\circ}$ that ${ }^{\circ}$ the ${ }^{\circ}$ ion ${ }^{\circ}$ species mainly consist of both a $(16: 0 / 16: 1)(18: 1 / 16: 0)-C L$ and a $(16: 0 / 16: 1)(16: 0 / 18: 1)-C L$ isomer.

\section{Conclusions}

The above results demonstrate that structural characterization of cardiolipin can be achieved by multiple stage $\left(\mathrm{MS}^{3}\right)$ tandem mass spectrometry with ESI in negative-ion mode. The tandem quadrupole production spectra or the $\mathrm{MS}^{2}$-spectra from ITMS provide structural information regarding the identity of the fatty acyl substituents and the information for assignment of the diacylphosphatidyl moieties attached to $1^{\prime}-$ or $3^{\prime}$ position of the central glycerol. The $\mathrm{MS}^{3}$ spectra or source CAD product-ion spectra of the diacylphosphatidyl fragment anions provide the structural information to reveal the position of the fatty acyl substituents on the glycerol backbone. Product-ion spectra arising from the $[\mathrm{M}-2 \mathrm{H}]^{-}$ions are also useful and provide complementary information to confirm the structure. However, standard cardiolipins with various fatty acyl substituents are required to confirm the assignment described above. The limited mass window for precursor ion selection in ITMS and TSQ instrument has also restricted its application in this study, because homologous ions differentiated by two daltons in biological extract are often inseparable from isotopic ions and therefore are subjected to collision dissociation simultaneously. In addition, assignment of doubly-charged fragment ions is also restricted by the limited resolving power of the quadrupole analyzers. More improvements in resolution and in selectivity of precursor ions are required for unambiguous structure characterization. Therefore, the implementation of analyses with high resolving power instrument with $\mathrm{MS}^{\mathrm{n}}$ capability, such as FT-ICR, may have an impact in the structural determination of more complex lipids such as CL in future.

\section{Acknowledgments}

This research was supported by US Public Health Service grants P41-RR-00954，R37-DK-34388， P60-DK-20579， P01-HL-57278, P30-DK-56341 and a grant (996003) from the Juvenile Diabetes Foundation.

\section{References}

1. LeCocq, J.; Ballou, C. E. On the structure of cardiolipin. Biochemistry 1964, 155, 976-980.

2. Powell, G. L.; Jacobus, J. The nonequivalence of the phosphorus atoms in cardiolipin. Biochemistry 1974, 13, 4024-4026.

3. Pangborn, M. C. Isolation and purification of a serologically active phospholipid from beef heart. J. Bio. Chem. 1942, 143, 247-256.

4. White, D. A. The phospholipid composition of mammalian tissues. In Form and function of phospholipids; Ansell, G. B.; Hawthorne, J. N.; Dawson, R. M. C., Eds.; Elsevier Publishing: New York, NY, 1973; p 441.

5. Hatch, G. M. Cardiolipin: Biosynthesis, remodeling and trafficking in the heart and mammalian cells. Int. J. Mol. Med. 1998, 1, 33-41.

6. Hatch, G. M. Regulation of cardiolipin biosynthesis in the heart. Mol. Cell Biochem. 1996, 159, 139-148.

7. Ostrander, D. B.; Sparagna, G. C.; Amoscato, A. A.; McMillin, J. B.; Dowhan, W. Decreased cardiolipin synthesis corresponds with cytochrome $c$ release in palmitate-induced cardiomyocyte apoptosis. J. Biol. Chem. 2001, 276, 38061-38067.

8. McMillin, J. B.; Dowhan, W. Cardiolipin and apoptosis. Biochim. Biophys. Acta 2002, 1585, 97-107.

9. Hoch, F. L. Cardiolipin and biomembrane function. Biochim Biophys. Acta 1992, 1113, 71-133.

10. Valianpour, F.; Wanders, R. J. A.; Barth, P. G.; Overmars, H.; van Gennip, A. H. Quantitative and compositional study of cardiolipin in platelets by electrospray ionization mass spectrometry: Application for the identification of Barth syndrome patients. Clin. Chem. 2002, 48, 1390-1397.

11. Schlame, M.; Towbin, J. A.; Heerdt, P. M.; Jehle, R.; DiMauro, S.; Blanck, T. J. Deficiency of tetralinoleoyl-cardiolipin in Barth syndrome. Ann. Neurol. 2002, 51, 634-663.

12. Hostetler, K. Y.; van den Bosch, H.; van Deenen, L. L. The mechanism of cardiolipin biosynthesis in liver mitochondria. Biochim. Biophys. Acta 1972, 260, 507-513.

13. Hirschberg, C. B.; Kennedy, E. P. Mechanism of the enzymatic synthesis of cardiolipin in Escherichia coli. Proc. Natl. Acad. Sci. U.S.A. 1972, 69, 648-651.

14. Schlame, M.; Rua, D.; Greenberg, M. L. The biosynthesis and functional role of cardiolipin. Prog. Lipid Res. 2000, 39, 257-288. 
15. Schlame, M.; Brody, S.; Hostetler, K. Y. Mitochondrial cardiolipin in diverse eukaryotes. Comparison of biosynthetic reactions and molecular acyl species. Eur. J. Biochem. 1993, 212, 727-735.

16. Schlame, M.; Otten, D. Analysis of cardiolipin molecular species by high-performance liquid chromatography of its derivative 1,3-bisphosphatidyl-2-benzoyl-sn-glycerol dimethyl ester. Anal. Biochem. 1991, 195, 290-295.

17. Beckedorf, A. I.; Schaffer, C.; Messner, P.; Peter-Katalinic, J. Mapping and sequencing of cardiolipins from Geobacillus stearothermophilus NRS 2004/3a by positive and negative ion nano ESI-QTOF-MS and MS/MS. J. Mass Spectrom. 2002, 37, 1086-1094.

18. Lesnefsky, E. S.; Stoll, M. S. K.; Minkler, P. E.; Hoppel, C. L. Separation and quantitation of phospholipids and lysophospholipids by high-performance liquid chromatography. Anal. Biochem. 2000, 285, 246-254.

19. Peter-Katalinic, J.; Fischer, W. $\alpha$-D-glucopyranosyl-, D-alanyland L-lysylcardiolipin from gram-positive bacteria: Analysis by fast bombardment mass spectrometry. J. Lipid Res. 1998, 39, $2286-2292$.

20. Hsu, F.-F.; Turk, J.; Shi, Y.; Groisman, E. A. Characterization of acylphosphatidylglycerols from Salmonella typhimurium by tandem mass spectrometry with electrospray ionization. J. Am. Soc. Mass Spectrom. 2004, 15, 1-11.

21. Rhoades, E. R.; Hsu, F.-F.; Torrelles, J. B.; Turk J, Chatterjee, D.; Russell, D. G. Identification and macrophage-activating activity of glycolipids released from intracellular Mycobacterium bovis BCG. Mol. Microbiol. 2003, 48, 875-888.
22. Hsu, F.-F.; Turk, J. Characterization of phosphatidylinositol, phosphatidylinositol-4-phosphate, and phosphatidylinositol4,5-bisphosphate by electrospray tandem mass spectrometry: A mechanistic study. J. Am. Soc. Mass Spectrom. 2000, 11, 986-999.

23. Hsu, F.-F.; Turk, J. Charge-driven fragmentation processes in diacyl glycerophosphatidic acids upon low-energy collisional activation. A mechanistic proposal. J. Am. Soc. Mass Spectrom. 2000, 11, 797-803.

24. Gilbin, D.; Hsu, F.-F.; Turk, J.; Gross, M. L. Mechanisms of characteristic phospholipid fragmentation, a theoretical study. Proceedings of 52nd ASMS Conference on Mass Spectrometry and Allied Topics; Nashville, TN, May, 2004.

25. Morrissey, B.; Tomas, M. C.; Mitchell, T. W.; Ung, A. T.; Pyne, S. G.; Blanksby, S. J. Negative ion phospholipid fragmentation: A mechanistic and regiochemical study. Proceedings of 52nd ASMS Conference on Mass Spectrometry and Allied Topics; Nashville, TN, May, 2004.

26. Hsu, F.-F.; Turk, J. Charge-driven and charge-remote fragmentation processes in diacyl glycerophosphoethanolamine upon low-energy collisional activation. A mechanistic proposal. J. Am. Soc. Mass Spectrom. 2000, 11, 892-899.

27. Henderson, T. O.; Glonek, T.; Myers, T. C. Phosphorus-31 nuclear magnetic resonance spectroscopy of phospholipids. Biochemistry 1974, 13, 623-628.

28. Kates, M.; Syz, J. Y.; Gosser, D.; Haines, T. H. pH-Dissociation characteristics of cardiolipin and its $2^{\prime}$-deoxy analog. Lipids 1993, 28, 877-882. 